\title{
Alcohol Interaction with Cocaine, Methamphetamine, Opioids, Nicotine, Cannabis, and $\gamma$-Hydroxybutyric Acid
}

\author{
Ashok K. Singh \\ Department of Veterinary Population Medicine, College of Veterinary Medicine, University of Minnesota, \\ St. Paul, MN 55108, USA; singh001@umn.edu; Tel.: +1-763-234-9655
}

Received: 9 January 2019; Accepted: 27 February 2019; Published: 7 March 2019

\begin{abstract}
Millions of people around the world drink alcoholic beverages to cope with the stress of modern lifestyle. Although moderate alcohol drinking may have some relaxing and euphoric effects, uncontrolled drinking exacerbates the problems associated with alcohol abuse that are exploding in quantity and intensity in the United States and around the world. Recently, mixing of alcohol with other drugs of abuse (such as opioids, cocaine, methamphetamine, nicotine, cannabis, and $\gamma$-hydroxybutyric acid) and medications has become an emerging trend, exacerbating the public health concerns. Mixing of alcohol with other drugs may additively or synergistically augment the seriousness of the adverse effects such as the withdrawal symptoms, cardiovascular disorders, liver damage, reproductive abnormalities, and behavioral abnormalities. Despite the seriousness of the situation, possible mechanisms underlying the interactions is not yet understood. This has been one of the key hindrances in developing effective treatments. Therefore, the aim of this article is to review the consequences of alcohol's interaction with other drugs and decipher the underlying mechanisms.
\end{abstract}

Keywords: alcohol; addiction; withdrawal; cocaine; methamphetamine (METH); nicotine; marijuana; opioids; $\gamma$-aminobutyric acid (GABA)

\section{Introduction}

Ethanol (referred as alcohol hereafter) and other illicit drugs-of-abuse (referred as drug(s) hereafter) such as cocaine, methamphetamine (METH), nicotine, opioids, cannabis, and $\gamma$-hydroxybutyric acid (GHBA) continue to be a major public health concern globally. In 2015, the estimated global prevalence among the adult population was $18.4 \%$ for daily heavy alcohol use, $15.2 \%$ for daily tobacco smoking, $3.8 \%$ for cannabis, $0.77 \%$ for amphetamine/methamphetamine (METH) use, $0.37 \%$ for opioid use, and $0.35 \%$ for cocaine use [1]. Europe had the highest prevalence of heavy episodic alcohol use and daily tobacco use. Approximately $6.6 \%$ (16 million) of Americans aged 12 or older reported heavy drinking, $22.7 \%$ (55 million) reported binge drinking, and 8.1\% (19.7 million) reported using drugs within the month prior to the survey [2]. However, drug abusers have historically tended to use more than one drug, a condition known as poly-drug abuse (defined as the concurrent or sequential abuse of more than one drug or type of drug, with dependence upon at least one [3]). Over the past several years, there has been an increasing tendency to combine narcotics, alcohol, sedatives, and/or stimulants [4,5].

Higgins et al. [6] have suggested that a combination of alcohol and other drugs of abuse such as cocaine, nicotine, opioids, or cannabis is popular among drug users, perhaps because of more intense feelings of 'high' beyond that perceived with either drug alone or less intense feelings of alcohol's aversive effects. Their survey of the cocaine-dependent patients showed that more than half of the subjects met criteria for current alcohol dependence, and in more than $50 \%$ of the occasions both drugs had been used simultaneously. In forensic studies of Budd et al. [7] and Marzuk et al. [8], 
cocaine and ethanol were frequently identified in biological samples from fatally injured drivers. Dani and Harris [9] showed that almost 20 million cigarette-smoking Americans, either abuse or were addicted to alcohol. According to Patrick et al. [10], 94\% of adults between the ages of 18 and 30 years have used alcohol in their lifetimes, and 56\% have also used marijuana. In general, alcohol is commonly co-abused with (i) psycho-stimulants such as METH, cocaine or nicotine, (ii) opioids such as morphine, fentanyl and heroin, (iii) cannabis that is now legal in many states of the United States, and (iv) a potent neuro-inhibitor $\gamma$-hydroxybutyric acid (GHBA) [11-13]. The adverse effects of mixing alcohol with other drugs can be dramatically severe $[14,15]$ that may hinder decision making, thinking, and neurocognitive capabilities [16-20].

Although mechanisms underlying the alcohol-drug interaction are not fully understood, two possibilities have been proposed: (i) common mechanisms including pharmacokinetics and pharmacodynamics [21,22] (Section 2) and (ii) specific mechanisms related to individual drug (Section 3). Earlier studies [23] have shown that alcohol increased the risk of heroin-related deaths, not due to any pharmacokinetic interaction, but due to pharmacodynamic interactions [22,23]. Conversely, alcohol modulated the effects of anti-inflammatory drugs via pharmacokinetic interactions [24]. Taken together, these observations indicate that an understanding of the alcohol-drug interaction may be essential to develop new strategies for treatment of addiction. Therefore, the aim of this review article is to decipher the common and drug-specific mechanisms underlying interaction between alcohol and cocaine, METH, nicotine, opioids, cannabis or GHBA. The overall hypothesis is that alcohol modulates the effects of cocaine, METH, nicotine, opioids, cannabis or GHBA via a common mechanism involving pharmacokinetics and pharmacodynamics, and/or drug-specific mechanisms addressed in Sections 2 and 3 , respectively (Figure 1).

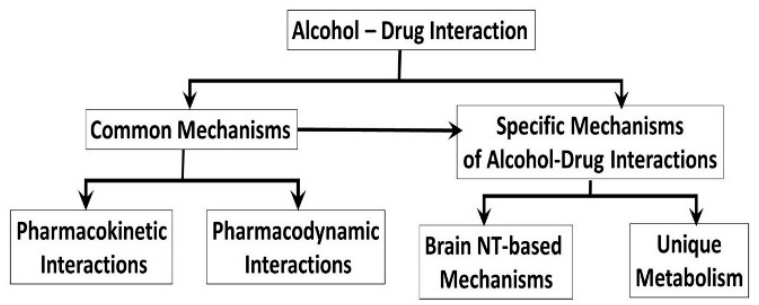

Figure 1. Proposed mechanisms for alcohol-drug interaction. NT: neurotransmitter systems and drug: cocaine, METH, nicotine, cannabis, opioids or GHBA.

\section{Common Mechanisms of the Alcohol-Drug Interactions}

People abusing alcohol or suffering from alcoholism tend to use multiple illegal and addictive drugs either sequentially or simultaneously [4,5]. Alcohol interacts with the co-abused drug and, additively or synergistically, modulate their effects via common pharmacokinetic (interference with the drug's metabolism) and pharmacodynamic (modulation of the drug mechanisms) mechanisms detailed in the following sub-sections.

\subsection{Pharmacokinetic Mechanisms of Alcohol-Drug Interactions}

Alcohol, when ingested orally, undergoes substantial first-pass metabolism pre-systemically in stomach and systemically in liver [25]. Alcohol dehydrogenases (ADHs) and aldehyde dehydrogenases (ALDHs) metabolize alcohol into acetaldehyde and acetate, respectively [25]. In liver, alcohol induces the cytochrome P450 enzymes CYP2E1, CYP1A2 and CYP3A4 (ADH >> CYP2E1 = (CYP1A2 + CYP3A4)) that metabolize alcohol [26], many drug and pharmaceuticals [27,28]. Alcohol-induced modulation of these enzymes may also affect the drug's pharmacokinetics (Figure 2, [11]). Accumulation of acetaldehyde may induce disulfiram-like reaction. In general, the following alcohol-drug interactions have been reported (Figure 2): 
i. In the absence of alcohol, drugs are metabolized via liver CYP enzymes and the metabolites are excreted [11,29].

ii. Acute low dose of alcohol exposure in alcohol-naïve subjects is metabolized to acetaldehyde mostly by ADHs, but acute high-dose or chronic alcohol exposure may be metabolized by both $\mathrm{ADH}$ and CYP enzymes listed above. CYP enzymes remain induced in alcohol abstinent subjected chronically exposed to alcohol [11].

iii. In alcohol-naïve subjects using alcohol and another drug, acute dose of alcohol may compete with the drug for the same set of CYP enzymes and inhibit a drug's metabolism. This may enhance the drug's availability and ensuing increase in the harmful side effects from the drug [29].

iv. In recently abstinent chronic alcohol drinker, many drug-metabolizing CYPs remain induced, thus decreasing the drug's availability and diminishing its effects for several weeks after drinking ceased. This suggests that a recently abstinent chronic drinker may need higher doses of medications than those required by nondrinkers to achieve therapeutic levels of certain drugs [30].

v. CYP enzymes activated by chronic alcohol consumption transform some drugs into toxic metabolites that can damage the liver or other organs [11].

These observations suggest that the drug and alcohol pharmacokinetics may play an important role on determining consequences of the alcohol-drug interaction. Earlier studies [30,31] have shown that the interaction pharmacokinetics can be predicted based on the metabolic profile of the drug. In general, alcohol exposure may modulate drug accumulation $\left(\mathrm{C}_{\max }\right.$ and $\left.\mathrm{AUC}\right)$ by modulating their metabolism and excretion.

Parker and Laizurs [32] studied effects of alcohol on pharmacokinetics of cocaine administered via oral and intravenous (i.v.) administration (Table 1). They showed cocaine area under the curve $\left(\mathrm{AUC}_{0-\infty}\right)$ and benzoylecgonine (BE) $\mathrm{AUC}_{0-\infty}$ values were approximately 5.5-fold and 2-fold, respectively, higher after i.v. compared with oral administration. Alcohol exposure significantly increased ( 3 to 4 folds) oral cocaine systemic bioavailability and peak concentration $\left(C_{\max }\right)$ values, respectively, but alcohol did not affect oral cocaine elimination half-life. The $\mathrm{BE} \mathrm{AUC}_{0-\infty}$ values were approximately 2.5-fold higher with alcohol cocaine co-administration than with oral cocaine given alone. The mean cocaethylene concentration was $30.9 \pm 7.3 \mathrm{ng} / \mathrm{mL}$. Compared with oral cocaine administered alone, alcohol co-administration also reduced the AUC ratio by $40 \%$. Alcohol did not significantly affect the AUC ratios for intravenous cocaine. Similar to the observations of Parker and Laizurs [32], Pan and Hedaya [33] also showed that alcohol exposure increased systemic bioavailability of intraperitoneal administered cocaine.

Table 1. Effects of alcohol on cocaine and benzoylecgonine pharmacokinetic parameters [33].

\begin{tabular}{ccccc}
\hline Indices & Oral Cocaine & $\begin{array}{c}\text { Oral Cocaine }+ \\
\text { Alcohol }\end{array}$ & $\begin{array}{c}\text { Intravenous } \\
\text { Cocaine }\end{array}$ & $\begin{array}{c}\text { Intravenous } \\
\text { Cocaine + Alcohol }\end{array}$ \\
\hline $\mathrm{AUC}_{0-\alpha}(\mathrm{mg} \cdot \mathrm{min} / \mathrm{L})$ & $15.0 \pm 4.7^{* \times}$ & $58.0 \pm 10$ & $83.1 \pm 4.7^{\times}$ & $110.3 \pm 22.5$ \\
\hline $\mathrm{CL}(\mathrm{L} / \mathrm{min})$ & $5.6 \pm 1.8^{* \times}$ & $1.6 \pm 0.35$ & $1.0 \pm 1.8^{\times}$ & $0.74 \pm 0.2$ \\
\hline $\mathrm{C}_{\max }(\mathrm{ng} / \mathrm{mL})$ & $116.0 \pm 98^{* \times}$ & $331.0 \pm 131$ & $2677 \pm 98$ & $2885 \pm 702$ \\
\hline $\mathrm{T}_{\max }(\mathrm{min})$ & $83.6 \pm 46$ & $99.8 \pm 32.5$ & & \\
\hline $\mathrm{T}_{1 / 2}(\mathrm{~min})$ & $85.2 \pm 6.6$ & $84.2 \pm 9.1$ & $75.0 \pm 6.6^{* \times}$ & $84.0 \pm 8.2$ \\
\hline $\mathrm{F}$ & $0.2 \pm 0.05^{\times}$ & $0.7 \pm 0.17$ & & $\mathrm{ND}$ \\
\hline $\mathrm{CE} \mathrm{C}_{\max }(\mathrm{ng} / \mathrm{mL})$ & $\mathrm{ND}$ & $30.9 \pm 7.3$ & $\mathrm{ND}$ & $407.0 \pm 110$ \\
\hline $\mathrm{BE} \mathrm{AUC} \mathrm{C}_{-\alpha}(\mathrm{mg} \cdot \mathrm{min} / \mathrm{L})$ & $172.0 \pm 46^{* \times}$ & $410.0 \pm 82$ & $375.0 \pm 46$ & $3.7 \pm 0.6$ \\
\hline $\mathrm{BE} / \mathrm{cocaine} \mathrm{AUC}{ }_{0-\alpha}$ & $11.9 \pm 3^{* \times}$ & $7.1 \pm 1.5$ & $4.9 \pm 3$ & \\
\hline $\mathrm{AUC}:$ ar
\end{tabular}

AUC: area under the plasma concentration-time curve, CL: clearance, $C_{\max }$ : maximum concentration, $\mathrm{T}_{1 / 2}$ elimination half-life, $\mathrm{T}_{\max }$ : time to $\mathrm{C} \max$, BE: benzoylecgonine. ${ }^{*} p<0.05$ compared with intravenous cocaine, $\times p<0.05$ compared with corresponding alcohol group given by the same route. 
The pharmacokinetics of alcohol-cocaine interaction is determined by cocaine's complex metabolic pathways (Figure 2) involving (i) pre first-pass and first-pass metabolism of cocaine to form $\mathrm{BE}$ and ecogonine methyl ester, (ii) conversion of cocaine to norcocaine by hepatic butyrylcholinesterase and p450 enzymes, and (iii) alcohol mediated formation of cocaethylene and norcocaethylene [34]. Patrick et al. [35] have shown alcohol to be a potent inhibitor of carboxyesterases and butyrylcholinesterase, resulting in accumulation of cocaine in the body. Parker et al. [32] have shown that alcohol suppressed first pass metabolism and elimination of cocaine. Taken together, these observations suggest that alcohol exposure may increase cocaine bioavailability and toxicity.

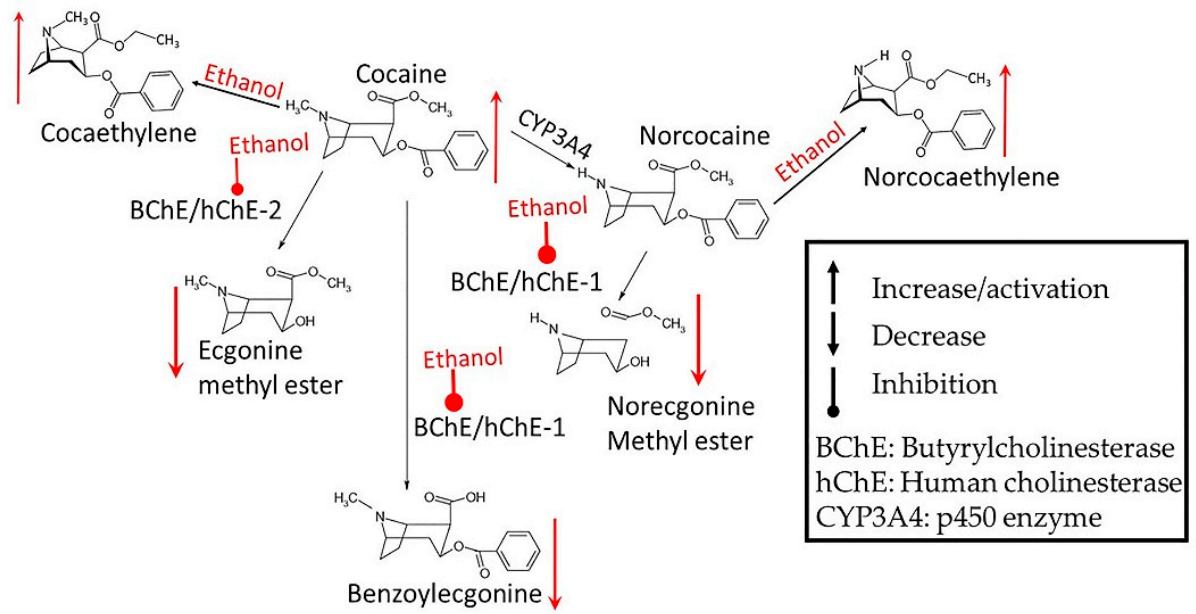

Figure 2. Effects of alcohol exposure on cocaine metabolism.

Alcohol, in addition to interacting with cocaine, also interacts with other drugs, albeit to different degrees. Li et al. [36] have shown that alcohol increased absorption and $\mathrm{C}_{\max }$ of METH and its metabolite, amphetamine (AP) without altering their elimination. They also suggested that an alcohol-induced increase in toxicity of METH may be due to pharmacodynamics mechanisms. Adir et al. [37], Rose et al. [38] and Ferguson et al. [39] have provided indirect evidence that alcohol alters distribution and metabolism of nicotine, thus altering its toxicity. Cannabis and opioids, on the other hand poorly respond to alcohol exposure. Toenne et al. $[40,41]$ have shown that alcohol increased half-life and decreased blood concentrations of cannabis but did not affect concentrations of its metabolites such as 11-OH- tetrahydrocannabinol (THC) and 11-nor-9-carboxy THC. Hartman et al. [42] and Lukas et al. [43] reported significant increases in THC and cannabidiol (CBD) concentrations, while two studies found no change. Likely, alcohol did not modify metabolism and pharmacokinetics of opioids.

\subsection{Pharmacodynamics of Alcohol-Drug Interactions}

Pharmacodynamics defines (i) the effects of alcohol and drug in body, especially at the target sites, and (ii) how drug combinations influence each other's effects directly [44-46]. Figure 3 describes pharmacodynamic interactions of alcohol (a neuro-inhibitor) with neuro-stimulatory drugs (such as cocaine, METH or nicotine) and neuro-inhibitory drugs (such as opioid, cannabis and GHBA). In general, the following alcohol-drug pharmacodynamic interactions have been reported:

i. The acute neuro-inhibitory effects of the alcohol, opioids, cannabis and GHBA are caused via development of inhibitory postsynaptic potential (IPSP). The acute neuro-excitatory effects of cocaine, METH, and nicotine cause development of excitatory postsynaptic potential (EPSP) [11]. Therefore, acute alcohol exposure may attenuate the effects of neuro-stimulatory drugs but augments the effects of neuro-inhibitory drugs (Figure 4A). As an example, alcohol cause neuro-inhibition by inducing $\mathrm{Cl}^{-}$influx into the neurons [47], resulting in development of neural membrane IPSP $[48,49]$ that antagonizes the effects of stimulatory drugs, but additively or synergistically augment the effects of inhibitory drug. 
ii. Chronic alcohol and drug exposure results in in development of tolerance and addiction via a common addiction mechanism (Figure 3). Therefore, chronic alcohol exposure may negatively impact addictive effects of both excitatory and inhibitory drugs.

iii. Figure 4 shows receptor overlap in development of alcohol, nicotine, and psycho-stimulant(such as cocaine and METH) dependence. The genes listed in Figure 4 have received strong statistical and biological (knockout studies) support for association with multiple substances [50]. The nAChR gene variants such as gene cluster CHRNA5/A3/B4 encoding $\alpha 3, \beta 4$, and $\alpha 5 \mathrm{nAChR}$ are associated strongly with poly-drug addiction [51-54]. The possible role of $\mathrm{nAChR}$ in alcohol dependence is further validated by the observation that varenicline, a partial agonist at $\alpha 4 \beta 2$ $\mathrm{nAChRs}$ and a full agonist at the $\alpha 7 \mathrm{nAChR}$ [55] reduced alcohol craving and total alcohol consumption in patients with alcohol use disorders $[56,57]$.

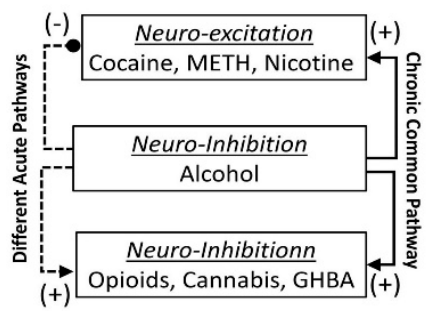

Figure 3. Proposed interaction between alcohol and Drug. (+): alcohol augments the effects, and (-): alcohol antagonizes the effects.

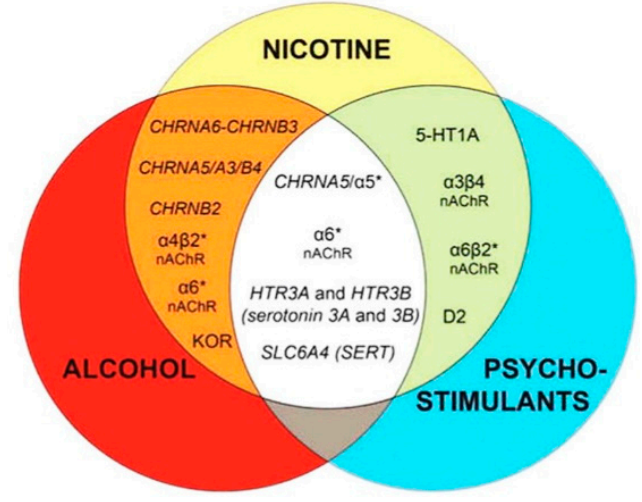

Figure 4. Overlapping receptor systems involved in nicotine and alcohol or psychostimulant dependence. Genetic and pharmacological studies in both humans and rodents suggest that co-use of nicotine and alcohol or psychostimulants is mediated, in part, by activity at overlapping substrates. In particular, cholinergic and serotonergic systems underlie reward-related behaviors, including drug intake, preference, and dependence to all three drugs of abuse. Common addiction genes are described by Cross et al [50] and Li and Burmeister [58]. Abbreviations: *: Nicotinic Acetylcholine Receptors (nAChRs) containing other subunits, ANKK1: ankyrin repeat and kinase domain 1, CHRN: cholinergic receptor nicotinic, C: CHRN, D2: dopamine receptors, Glu: glutamate, HTR: 5-hydroxytryptamine (serotonine) receptorts, KOR: kappa opioid receptor, NMDA: N-methyl-D-aspartate, SLC6A4: solute carrier family 6 member 4 . Reproduced from [50] with permission.

A relatively older study conducted by Pan and Hedaya [33] have described negative effects of alcohol on pharmacodynamics of cocaine by using indices that relate brain cocaine concentrations with biological functions (Table 2). For example, $\mathrm{E}_{\max }$ describes brain DA concentration measured at maximum change in the brain cocaine concentration $\left(\delta \mathrm{C}_{\max }\right)$, and $\mathrm{EC}_{50}$ describes a cocaine concentration that caused $50 \% \mathrm{E}_{\max }$ response. Similarly, the cardiac indices assessed rate constants for the direct effects of cocaine on cardiac functions. An increase in $\mathrm{E}_{\max }$ indicates augmentation of DA release at $\delta C_{\max }$ cocaine concentrations. These studies showed that cocaine + saline administration increased the brain extracellular fluid (ECF) DA and nucleus accumbens (NAc) cocaine concentrations 
that peaked within 20-40 min, then gradually declined. Alcohol co-administration with cocaine caused significantly higher estimate for $E_{\max }$ values (not significant) but significantly lower $\mathrm{IC}_{50}$ values (Table 2). This suggests that alcohol exerts a direct stimulatory effect on the brain DA system in cocaine administered subjects. Unlike the neurological effects, the cardiovascular parameters were not different after cocaine + normal saline and cocaine + alcohol administration. This suggests that the same brain ECF cocaine concentration produced higher neurochemical response after co-administration of alcohol, causing more intense and longer lasting euphoric effects. This stronger response may be caused by the pharmacologically active metabolite cocaethylene [59].

Table 2. Pharmacodynamic parameters defining the effects of alcohol on Cocaine's adverse effects in Wistar Rats (Mean \pm SE, $n=8$ ) [33].

\begin{tabular}{ccc}
\hline Pharmacodynamic Parameters & Cocaine (ip) $^{\mathbf{a}}+$ Normal Saline & Cocaine (ip) $^{\mathbf{a}}+$ Alcohol (po) \\
\hline & A. Neurochemical & \\
\hline $\mathrm{E}_{\max }(\%$ of baseline $)$ & $850 \pm 200$ & $1550 \pm 640$ \\
$\mathrm{EC}_{50}(\mathrm{ng} / \mathrm{mL})$ & $3400 \pm 580$ & $2000 \pm 650$ \\
$\mathrm{~N}$ & $1.23 \pm 0.17$ & $2.31 \pm 0.29^{\mathrm{b}}$ \\
\hline & B. Cardiovascular & \\
\hline $\mathrm{k}_{\text {in }}(\%$ of baseline $/ \mathrm{min})$ & $23.8 \pm 5.1$ & $36.0 \pm 13.0$ \\
$\mathrm{~K}_{\text {out }}\left(\mathrm{min}^{-1}\right)$ & $0.218 \pm 0.047$ & $0.31 \pm 0.11$ \\
$\mathrm{I}_{\max }$ & $0.304 \pm 0.033$ & $0.307 \pm 0.035$ \\
$\mathrm{IC}_{50}(\mathrm{mg} / \mathrm{mL})$ & $6700 \pm 2100$ & $5600 \pm 710$ \\
$\mathrm{R}_{\max }(\%$ of baseline $)$ & $146 \pm 6.9$ & $148 \pm 8.9$ \\
$\mathrm{~N}$ & $3.0 \pm 1.5$ & $3.6 \pm 1.9$ \\
\hline
\end{tabular}

${ }^{\text {a }}$ : Cocaine dose, $30 \mathrm{mg} / \mathrm{kg}$; alcohol dose, $5 \mathrm{~g} / \mathrm{kg}^{\mathrm{b}}{ }^{\mathrm{s}}$ : Significantly different from the cocaine+normal saline treatment group $(p<0.05)$. Abbreviations: $\mathrm{E}_{\max }$ : ECF DA concentration measured at maximum change in brain ECF cocaine concentration, $\mathrm{EC}_{50}$ : brain $\mathrm{ECF}$ cocaine concentration causing $50 \% \mathrm{E}_{\max }$ response, $\mathrm{n}$ : sigmoidicity factor, $\mathrm{k}_{\text {in }}$ : apparent 0 -order rate constant for response production, $\mathrm{k}_{\text {out }}$ : 1 st-order rate constant for response dissipation, $\mathrm{I}_{\max }$ : the maximum inhibition factor producing the response, $\mathrm{IC}_{50}$ : cocaine concentration that produces $50 \%$ effect, and $\mathrm{R}_{\max }$ maximum response.

Robinson et al. [60] have demonstrated that an antiepileptic drug, levetiracetam (LEV) that is a potent inhibitor of Glu-induced neuro-excitation, differentially modulated the effects of cocaine and alcohol. LEV pretreatment attenuated the development of locomotor sensitization to repeated alcohol exposure but enhanced both acute locomotor stimulation by cocaine and development of locomotor sensitization following repeated exposure. Although a possible mechanism underlying the ability of LEV to differentially modulate the effects of alcohol and cocaine is not fully understood, studies have proposed that the two substances may act at different sites of Glu ergic neurotransmission in

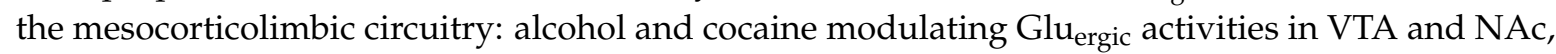
respectively [61]. Acute cocaine administration stimulated Glu release in NAc, but not in VTA [62], while acute alcohol increased the firing rate of $\mathrm{DA}_{\text {ergic }}$ VTA neurons [63]. These differences may explain in part why LEV blocks the development of locomotor sensitization to alcohol but not to

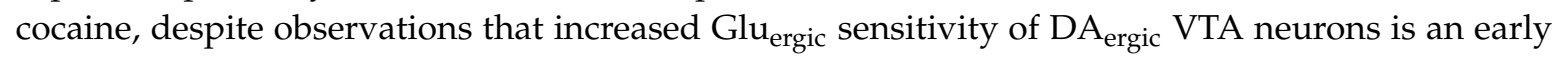
triggering event in sensitization to both cocaine and alcohol [64].

Taken together, these observations suggest that the neuro-inhibitory and neuro-excitatory substances may cause acute effects by diverse mechanisms, but chronic addictive effects via a common mechanism. Alcohol may augment the acute effects of neuro-inhibitory but attenuate the acute effects of neuro-excitatory drug. However, alcohol may augment the addictive effects of both groups of drugs.

\section{Specific Alcohol-Drug Interactions}

As discussed earlier, the brain neurotransmitter (NTs) systems including, but not limited to, endogenous opioids (eOPs), DA, GABA, glutamate (Glu), glycine (Gly), serotonin (5-HT), excitatory amino acids (EAAs) and their respective receptors play important roles in rewards, aversive effects and 
addictive effects of alcohol and other drugs [65]. In drug-free situations, all NTs interact with each other (positively (+) or negatively (-) as shown in Table 3) and maintain a NT balance. Depending on the type of substance (alcohol, cocaine, METH, nicotine, opioids, cannabis, and GHBA), different groups of NTs have been suggested as direct targets. For example, GABA and Glu are key targets of alcohol that simultaneously increases inhibitory neurotransmission through GABA and reduces excitatory neurotransmission through Glu [66]. Unlike alcohol, DA and ACh are direct targets for amphetamine and nicotine, respectively. Amphetamine directly increases the DA level in the synaptic cleft [67], whereas nicotine mimics psychopharmacological effects of ACh and modulates DA release [68,69]. In addition to the direct effects, addictive substances can also modulate other NTs through indirect pathways. For example, alcohol's direct effect on the striatum Glu may modulate, GABA ergic activity in the NAc. Direct and indirect mechanisms both may play an important role in alcohol-Drug interactions.

Table 3. Positive (+) or negative (-) interactions among six neurotransmitter systems in the brain. Abbreviations are shown in the text [70].

\begin{tabular}{ccccccc}
\hline NTs & Glu & GABA & $5-H T$ & DA & NA & ACh \\
\hline Glu & & + & + & + & - & + \\
\hline GABA & - & & - & - & - & - \\
\hline $5-H T$ & + & - & & + & + & - \\
\hline DA & - & - & - & & + & - \\
\hline NA & - & - & - & + & & - \\
\hline ACh & + & + & + & + & + & \\
\hline
\end{tabular}

An interactive mechanistic diagram showing possible roles of the brain NT and receptor systems in different brain regions are shown in Figure 5A. The details are discussed in the figure legend. As shown in Figure 5B, a direct alcohol-induced activation of hypothalamus $\mathrm{OP}_{\text {ergic }}$ neurons may indirectly modulate $\mathrm{GABA}_{\text {ergic }}$ neurons followed by modulation of $\mathrm{DA}_{\text {ergic }}$ neurons. This may modulate the effects of amphetamine that acts by directly activating $\mathrm{DA}_{\text {ergic }}$ neurons. Thus, direct and indirect effects of alcohol may modulate effects of co-administered drug. The following paragraph includes a brief discussion of the overall mechanism of action of alcohol.

Acute alcohol exposure, in addition to activating the alcohol metabolizing enzymes such as alcohol dehydrogenase (ADH), acetaldehyde dehydrogenase (ALDH) and microsomal P450 enzymes, also causes a psychotropic depression of the CNS, leading to various behavioral and biological alterations $[25,26]$. Alcohol-induced depression is causally related to (i) direct increase in $\mathrm{GABA}_{\text {ergic }}$

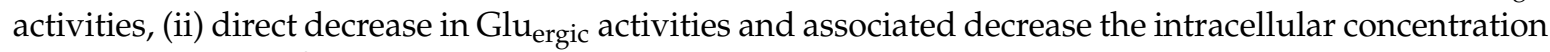
of calcium ions $\left(\mathrm{Ca}^{2+}\right)$, and (iii) indirect modulation of $\mathrm{DA}_{\text {ergic }}, 5 \mathrm{HT}_{\text {ergic }}$ and $\mathrm{ACh}_{\text {ergic }}$ activities [71-73]. All processes, except the $\mathrm{DA}_{\text {ergic }}$ activity, may be negatively regulated by acute alcohol exposure [74]. In contrast, chronic alcohol use causes tolerance and addiction by (i) down-regulating GABA receptors and phosphorylation of ERK which is regulated by GABA receptors, and (ii) activating Glu receptors in the hippocampus that is involved in seizures development during alcohol withdrawal [74-76]. Chronic alcohol abuse may also prevent activation of the memory circuit and the explicit memory supported by the hippocampus [77]. Alcohol withdrawal in addicted subjects decreases GABAR but increases GluR activities, resulting in strong neuro-stimulation (red arrows). Figure 5B shows multiple neurotransmitters and neuromodulators that collectively mediate the reward-profile of alcohol [78]. In general, alcohol directly modulated $\mathrm{OP}_{\text {ergic }}, \mathrm{GABA}_{\text {ergic }}$ and $\mathrm{Glu}_{\text {ergic }}$, and indirectly modulated $\mathrm{DA}_{\text {ergic }}, 5-\mathrm{HT}_{\text {ergic }}$ and cholinergic $\left(\mathrm{ACh}_{\text {ergic }}\right)$ presynaptic neurons, thus modulating the release of neurotransmitters and ensuing modulation of postsynaptic neurons. Binding of neurotransmitters to the postsynaptic receptors release may modulate respective behavioral traits. 


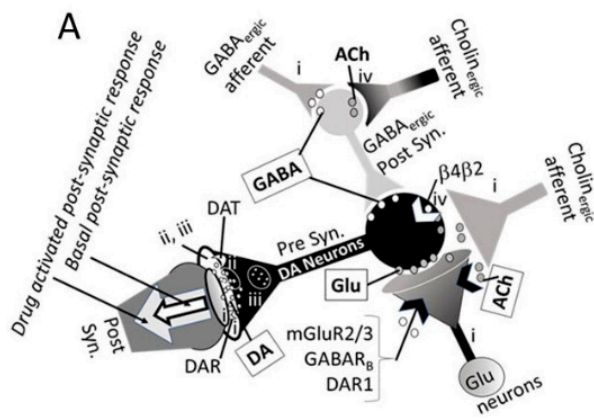

(A)

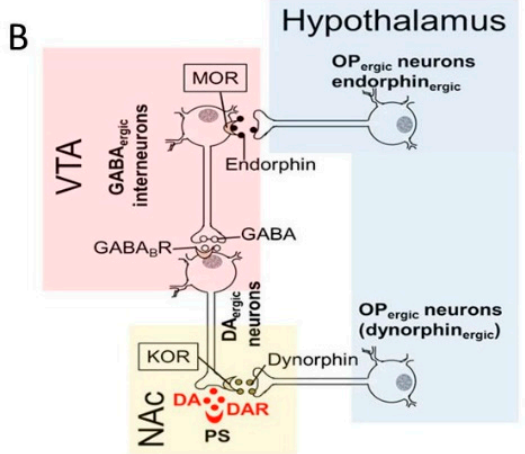

(B)

Figure 5. (A) Possible roles of $\mathrm{Glu}_{\text {ergic }}, \mathrm{GABA}_{\text {ergic }}$ and $\mathrm{ACh}_{\text {ergic }}$ neurons in regulation of ventral tegmental area (VTA) $D_{\text {ergic }}$ neuron excitability. Opioid (OP) receptors are not shown in this diagram). The presynaptic $D_{\text {ergic }}$ neurons (1) express $G_{A B A} R, D A R 1, m G l u R 2 / 3$ and nicotinic ( $\alpha 7$ and $\alpha 4 \beta 2$ ) receptors thus the neuronal activity is modulated by Glu, GABA, ACh and nicotine, and (2) received

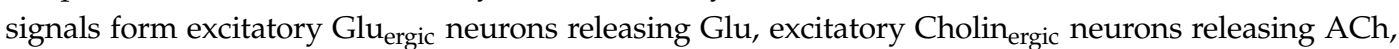
and inhibitory $\mathrm{GABA}_{\text {ergic }}$ neurons releasing GABA. The released NTs bind to their respective receptors on $\mathrm{DA}_{\text {ergic }}$ neurons and elicit excitatory (depolarization) or inhibitory (hyperpolarization) response. The Glu ergic $_{\text {neurons also express } m G l u R 2 / 3, A C h R, ~ G A B A} \mathrm{R}$ and DAR1 receptors, thus the neuronal activity is modulated by Glu, GABA and $A C h$. The $\mathrm{GABA}_{\text {ergic }}$ interneurons receive receptors signals from $\mathrm{GABA}_{\text {ergic }}$ and $\mathrm{Cholin}_{\text {ergic }}$ efferent. (B) Interaction of $\mathrm{OP}_{\text {ergic }}$ neurons (endorphin ergic $_{\text {neurons }}$

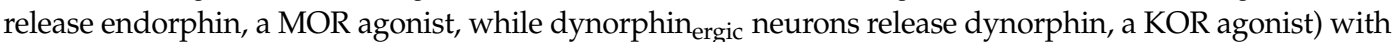
$\mathrm{GABA}_{\text {ergic }}$ interneurons and $\mathrm{DA}_{\text {ergic }}$ neurons. The $\mathrm{DA}_{\text {ergic }}$ neurons from the VTA project to ANc and are under tonic inhibition by $\mathrm{GABA}_{\text {ergic }}$ interneurons that are under direct inhibition by endorphin ergic $_{\text {. }}$ neurons from the hypothalamus Therefore, stimulation of endorphin release in VTA inhibits GABA ergic $_{\text {gic }}$ interneurons and ensuing disinhibition of the $\mathrm{DA}_{\text {ergic }}$ neurons, leading to increased DA release in NAc. Acute alcohol stimulates endorphin and met-enkephalin release, leading to an increase in DA release, while chronic alcohol stimulates dynorphin release that could attenuate DA release in the NAc. Abbreviations: DA: dopamine, DAR: DA receptors, DAT: DA transporter, Glu: glutamate, and $\alpha 7$ and $\alpha 4 \beta 2$ : nicotinic receptors. The VTA DA ergic $_{\text {nic }}$ neurons receive signals from $\mathrm{Glu}_{\text {ergic }}$ (releases excitatory

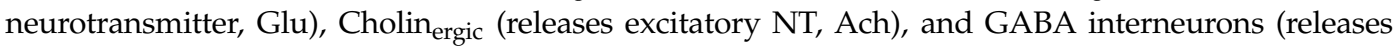
inhibitory neurotransmitter, GABA) that receive signals from $\mathrm{GABA}_{\text {ergic }}$ (releases GABA) and $\mathrm{Cholin}_{\text {ergic }}$ (releases ACh) neurons. Binding of GABA to its receptors on. GABA ergic afferent neurons releases GABA inhibits GABA interneurons, thus activating the $\mathrm{DA}_{\text {ergic }}$ neurons. Symbol-i: the sites of actions for alcohol, symbol-ii: the site of action for cocaine, and symbol-iii: the site of action for nicotine.

These observations suggest that acute and chronic alcohol exposure may target different sets of the CNS NTs and, therefore, differently modulate the effects of excitatory and inhibitory drug. Acute alcohol exposure, due to its depressive effects, may augment the effects of neuro-inhibitory drugs (cannabis or GHBA), but suppress the effects of neuro-stimulatory drugs (cocaine, METH and nicotine). However, chronic alcohol exposure may augment the neuro-stimulatory drugs but suppressing neuro-inhibitory Drugs. Interaction of alcohol with other drugs are discussed below.

\subsection{Alcohol-Cocaine Interaction}

Cocaine is a powerful addictive, psychoactive, stimulant drug illegally available on the streets as a fine, white powder. Whatever the form, cocaine acts as a strong stimulant substance that can (i) provide a rapid-onset of rewarding high, (ii) speed up various physiologic processes via its CNS effects, and (iii) influence both short- and long-term mental health. Acevedo-Rodriguez et al. [79] have shown that cocaine, at concentrations around $0.5 \mu \mathrm{M}$ that is readily achievable in cocaine abusers, inhibited the DA transporter (DAT)-mediated uptake of DA. At concentration around $4 \mu \mathrm{M}$, cocaine inhibited nAChRs and altered DA release [80]. At cocaine level $\geq 20 \mu \mathrm{M}$, its anesthetic effect may be 
triggered (Figure 6). This suggests that the mechanistic effects shown in Figure 6 may contribute to the cocaine-induced increases the ratio of phasic to tonic DA release and thus potentially enhances its reinforcing abilities [81].

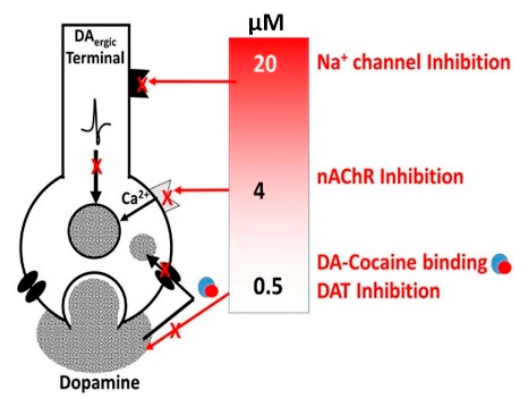

Figure 6. Diagram showing that cocaine may inhibit DAT-mediated DA uptake and DA release via nAChRs and $\mathrm{Na}^{+}$channels in a dose-dependent manner.

Epidemiological studies have shown that, compared to the control subject (cocaine free), the prevalence of alcohol use was found $89 \%$ higher among cocaine dependents [82,83], possibly due to the perception of higher increase of reward effects when alcohol and cocaine were co-administered compared to either drug administered alone [84-86]. In a study conducted on rats, intravenous injections of cocaine increased alcohol drinking, suggesting that cocaine potentiated alcohol seeking [87]. A preclinical study has shown a higher susceptibility of the reinforcing effects of cocaine in selectively bred alcohol preferring (P) rats compared to its outbred Wister rats, suggesting a higher sensitivity of alcoholics to the reinforcing effects of cocaine [88] Similarly, it has been revealed that genetically predisposed subjects for alcohol dependence have a higher rate to be cocaine dependents [89]. This suggests that alcohol and cocaine, when co-administered, potentiate the effects of individual drugs. Different aspect of interaction between alcohol and cocaine exposure are shown in Figure 7 and described below.

Cocaine and alcohol co-administration generates a unique metabolite, cocaethylene that is equipotent in inhibition of binding to the dopamine and serotonin reuptake complex [90,91]. Cocaethylene may be less anxiogenic and more reinforcing [92,93], but it is more lethal than cocaine [94] Concurrent use of cocaine and alcohol has been associated with greater risk of sudden death than after cocaine alone [95]. Cocaethylene has been detected in wastewater, an observation that has been used as evidence of cocaine and alcohol co-abuse in urban area. In addition, cocaethylene concentrations in wastewater was significantly higher during weekends compared to weekdays, further suggesting a higher co-abuse of cocaine and alcohol [96].

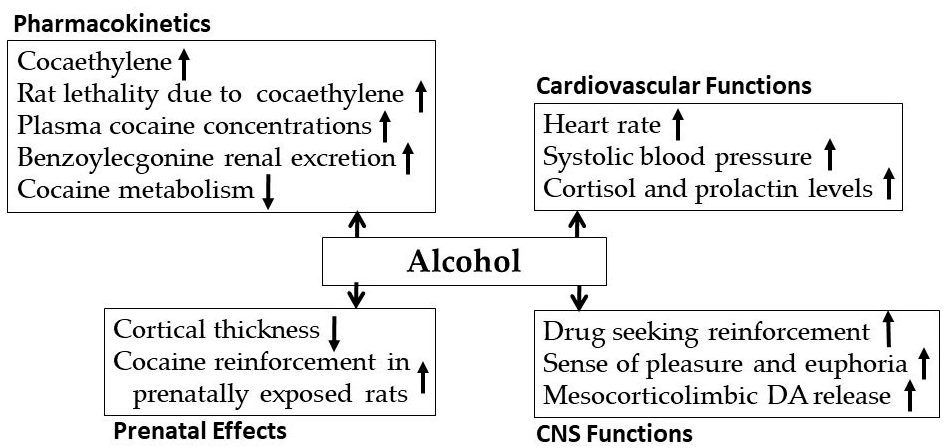

Figure 7. Effects of alcohol exposure on cocaine's pharmacokinetics, cardiovascular function, CNS functions and prenatal effects.

Alcohol administration has been shown to increase the plasma concentration of cocaine [97], leading to an increase in cocaethylene concentration in plasma and decrease in benzoylecgonine renal excretion [98]. Although alcohol ingestion did not alter cocaine half-life, it significantly increased 
cocaethylene's half-life [99], thus increasing the exposure to cocaethylene's deteriorating toxic effects. Cocaine and alcohol co-exposure also has deleterious effects on cardiovascular and endocrine systems as evidenced by an increase in heart rate, systolic blood pressure, cortisol, and prolactin concentrations, and cerebral blood perfusion [100]. It has been shown that cerebral hypo-perfusion was more common among individuals taking cocaine and alcohol together compared to individuals taking cocaine or alcohol alone [101,102].

Several indices of neuropsychological performances such as intelligence, memory, verbal learning were found to be negatively affected by the concurrent intake of cocaine and alcohol compared to either drug administered alone $[103,104]$. The sense of pleasure and euphoria increased in co-abuse of alcohol and cocaine and consequently elevated the risk of dependence and toxicity [105]. Alcohol and cocaine co-exposure increased extracellular DA concentration in the NAc, a region involved in the rewarding and reinforcing effects of drugs of abuse [106-108], compared to either drug administered alone in rats [109]. One recent study has demonstrated a significant interaction in prenatal co-exposure of cocaine and alcohol on cortical thickness in youths prenatally exposed to these drugs [110,111].

\subsection{Alcohol-Methamphetamine Interactions}

METH's main mechanism of action is its ability to increase in neuronal release of DA into the NAc, an effect mediated via alterations in both the DAT and the vesicular monoamine transporter-2 (VMAT-2) [112]. In addition, METH phosphorylates DAT via protein kinase C leads to internalization of DAT, thus impairing the normal function of DAT [113]. Concurrent with reuptake inhibition, METH also induces DA efflux into the synapse (Figure 8).

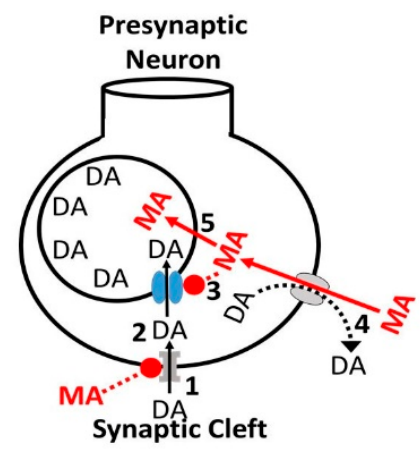

Figure 8. Mechanism of action of METH on DA neurotransmission. [113. 1: Methamphetamine (MA) inhibits DA reuptake, 2: MA phosphorylates DAT resulting in its internalization, 3: MA inhibits DA's synaptosomal uptake via vesicular monoamine-transporter 2 (VMAT-2), 4: intracellular uptake of MA reverse transports DA via DAT into the synaptic cleft, 5: MA diffuses into the synaptosome impairing DA storage.

Alcohol and METH, often used together, cause co-morbid disorder [113,114]. Approximately $77 \%$ of people diagnosed with amphetamine dependence also have an alcohol use disorder $[115,116]$. Within the population of METH users, alcohol consumption increases the probability of METH use by four-fold [117-119]. Figure 9 shows possible effects of concurrent alcohol and METH exposure. METH abusers frequently use alcohol to have a higher level of euphoric effects. But, alcohol may inhibit METH metabolism, resulting in higher blood METH concentration, with an increase in its stimulating effects on brain and heart, resulting in significant negative effects on mood, performance, and physiological behaviors [120]. Co-exposure to alcohol and METH also resulted in (i) synergistic depletions of DAT, SERT, and DA and 5HT content, and (ii) increase in LPS and COX-2 in rats [118,121]. This suggests that prior alcohol drinking may also increase the inflammatory mediators, thus enhancing neurotoxicity. 


\section{Pharmacokinetics}

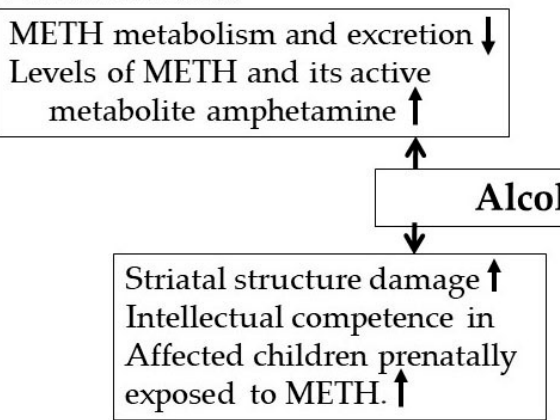

Prenatal Effects

\section{Cardiovascular Functions}

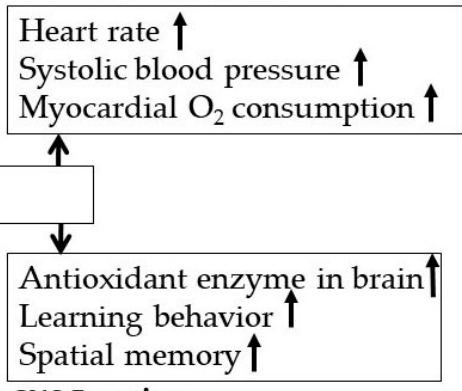

CNS Functions

Figure 9. Effects of METH exposure on alcohol's pharmacokinetics, cardiovascular function, CNS functions and prenatal effects.

Mendelson et al. [122] in humans and Wells et al. [123] in mouse have shown that in utero exposure of a combination of alcohol and METH may cause greater toxicity in offspring than either alcohol or METH. This interaction may be due to the increased production of reactive oxygen species (ROS) that alter signal transduction, and/or oxidative stress-induced damage to cellular macromolecules like lipids, proteins, and DNA, the latter leading to altered gene expression [123]. This may be causally related to the development of cardiac cytotoxicity associated with adverse cardiovascular effects. Andez-Lopez et al. [124] have shown that, in addition to alcohol-METH combination, the 3,4-Methylenedioxy-methamphetamine (Ecstasy) and alcohol combination also augmented euphoria and wellbeing than Ecstasy or alcohol alone. Subjects may feel euphoric and less sedated and might have the feeling of doing better, but actual performance ability continues to be impaired by the effect of alcohol.

\subsection{Nicotine}

Nicotine is a highly addictive substance of tobacco, acting via binding to the nicotinic acetylcholine (ACh) receptors or $\mathrm{nAChRs}$ that respond to the neurotransmitter ACh. Nicotine addiction is mediated through nAChR expressed on most neurons in the brain. Tolu and Eddine [125] showed that nAChR-mediated activation of GABA neurons in the VTA plays a crucial role in the control of nicotine-elicited $\mathrm{DA}_{\text {ergic }}$ activity (Figure 10). DA and GABA make a concerted effort to generate reinforcing actions of nicotine through $\mathrm{DA}_{\text {ergic }}$ neurons. Therefore, $\mathrm{GABA}_{\text {ergic }}$ neurons may be a potential drug development target for cessation of drug development.

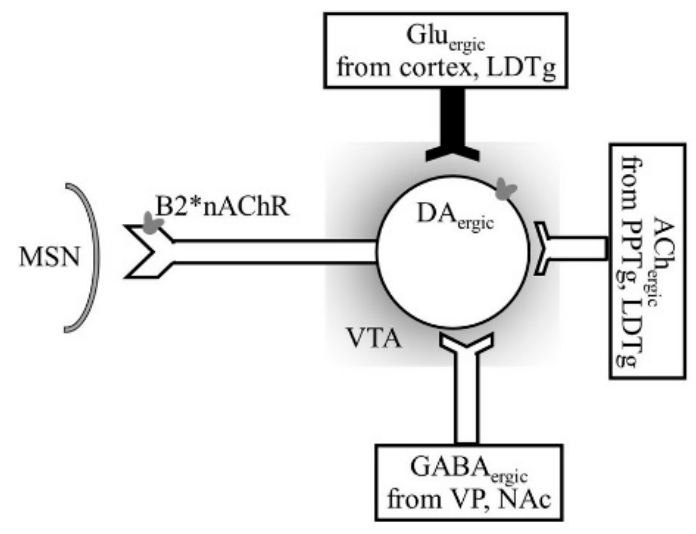

Figure 10. A schematic representation of the $\mathrm{ACh}_{\text {ergic }}$ signaling in VTA and afferents. The $\mathrm{DA}_{\text {ergic }}$ output neuron contains high-affinity b2-nAChRs that are inhibited by GABA releasing from $\mathrm{GABA}_{\text {ergic }}$ interneurons containing high-affinity b2-nAChRs. $\mathrm{GABA}_{\text {ergic }}$, $\mathrm{Glu}_{\text {ergic }}$ and $\mathrm{ACh}_{\text {ergic }}$ projections arrive from the ventral pallidum (VP), the laterodorsal tegmental nucleus and LDTg/PPTg pontine tegmental nuclei, respectively. $\mathrm{DA}_{\text {ergic }}$ neurons release DA in the NAc, which show biochemical alterations after alcohol exposure. 
Alcohol and cigarette smoking is the most common practice globally that may be most costly in terms of health and societal costs [126-128]. Nicotine dependents may have a high tendency to be alcohol dependents [129]. It has been reported that more than $80 \%$ of chronic alcohol users are also smokers [130-132]. In a preclinical study, rats chronically co-exposed to alcohol and nicotine showed higher nicotine self-administration as compared to drug self-administered alone [133]. The overall effects of alcohol-nicotine interaction are shown in Figure 11.

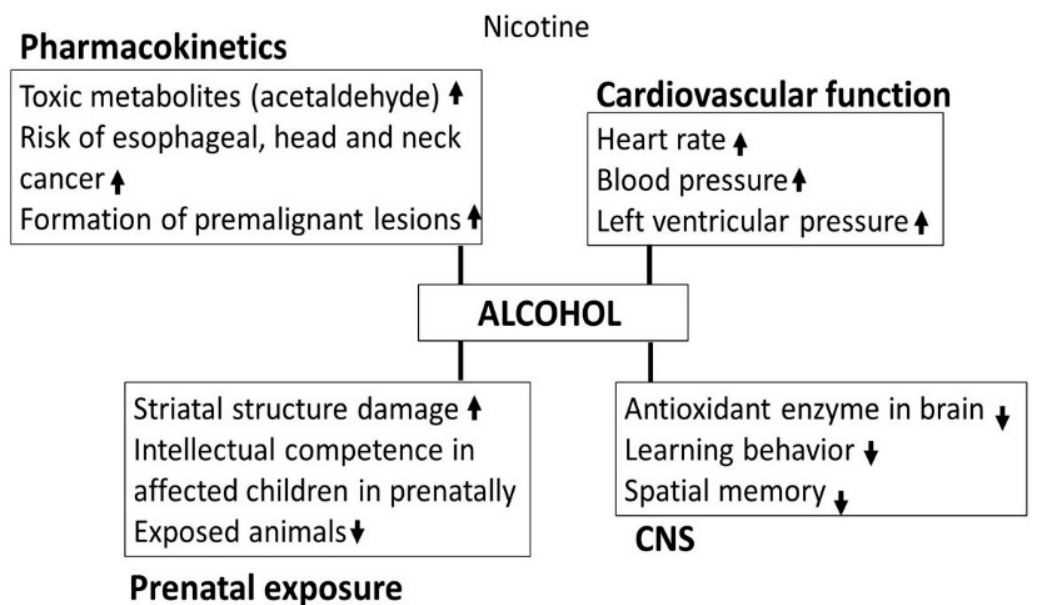

Figure 11. Effects of alcohol exposure on nicotine's pharmacokinetics, cardiovascular function, CNS functions and prenatal effects.

Blomqvist et al. $[134,135]$ have proposed that alcohol modulates the reinforcing effects of nicotine by directly interacting with the nAChRs, $\beta 2$ and $\beta 4[136,137]$. Lüscher and Malenka [138] have shown that chronic nicotine exposure triggers a conformational change in $\beta 4 \mathrm{nAChRs}$ that initiates various forms of synaptic plasticity and modify the VTA-DA neuron's responses to alcohol and alcohol drinking behaviors. Norbinaltorphamine (norBNI), a KOR antagonist, robustly increased alcohol and nicotine self-administration in adult male rats but not in female rats $[139,140]$. Taken together, these findings suggest that nicotine, from either tobacco or e-cigarette use, may increase the vulnerability of teenage boys to alcohol abuse.

\subsection{Alcohol-Opioid Interactions}

Opioids, addictive substances derived from the poppy seedpod, occurs as (i) a natural drug such as opium, morphine and codeine, and (ii) a synthetic drug such as dilaudid, demerol, oxycodone, vicodin, fentanyl, methadone or heroin. Opioids are commonly used analgesic agent with potential for abuse as street drug $[141,142]$. In body, the opioid drugs compete with the receptors for endogenous opioid peptides (eOP) such as $\beta$-endorphin, enkephalins, and dynorphins released by selective $\mathrm{OP}_{\text {ergic }}$ neurons. The eOPs, nOPs and sOPs bind to three families of opioid receptors (OPRs): $\mu$ (MOR), $\delta$ (DOR), and $\kappa(K O R)$ with differing affinities [143]. The three OP receptors (OPRs) are widely distributed in the brain regions involved in pain modulation, reward, stress responses, and autonomic control [144]. OPRs selectively interact with G-proteins (composed of two subunits, $G \alpha_{i}, \alpha_{s}$ or $\alpha_{o}$ and $\beta \gamma$ subunits) and form MOR-G $\alpha_{i} \beta \gamma$ for $\beta$-endorphin and endomorphin 1, DOR-G $\alpha_{o} \beta \gamma$ for enkephalins, and KOR-G $\alpha_{s} \beta \gamma$ for dynorphin and endomorphin 2 [145]. The OPR-G protein complex (such as MOR-G $\alpha_{i} \beta \gamma$ ), upon binding to an eOP or a sOP, dissociates into MOR-G $\alpha_{\mathrm{i}}$ subunit and $\beta \gamma$ subunits. MOR-G $\alpha_{\mathrm{i}}$ subunit directly inhibits adenylyl cyclase (AC) that reduces cAMP formation and activates inwardly rectifying $\mathrm{K}^{+}$ channels $\left(\mathrm{GIRK}^{+}\right)$, causing neuro-inhibition and ensuing analgesic response [146]. The $\beta \gamma$ dimer directly inhibits voltage-dependent $\mathrm{Ca}^{2+}$ channels [147]. Taken together, these changes block the presynaptic signal from activating postsynaptic terminal, thus causing analgesia. 
Acute alcohol exposure has been shown to potentiate the opioid-induced increase in analgesia and CNS depression, leading to serious side effects including respiratory distress, coma, and death $[148,149]$. Chronic alcohol exposure may develop coaddiction when addiction to one drug (such as an opioid) enhances craving for another such as alcohol [150-155]. A Canadian study has shown that approximately $82 \%$ of apparent opioid-related deaths from 2016 to 2017 also involved one or more type of non-opioid substances including alcohol [148]. Polettini et al. [156] have shown that heroin, a dangerous illegal opioid, can interact with alcohol and produce a sensation of greater pleasure than the two individually, while at the same time inhibiting the respiratory system. In addition, alcohol may exacerbate the neuronal situation by inhibiting heroin metabolism (pharmacokinetic mechanism) [157]. Despite the seriousness of the alcohol-opioid interaction, the underlying mechanisms are not fully understood. Therefore, the aim of proceeding sub-sections are to discuss combined effects of alcohol and opioid on analgesia, CNS inhibition and addiction.

Figure 12 shows signaling pathways for analgesic effects of opioids and effects of alcohol drinking on it. In addition to the OPRs, type-2 G-protein coupled inwardly rectifying potassium (GIRK2) channels are also implicated in analgesic action of opioid drugs (Figure 16) [158]. This hypothesis is supported by the observations that the analgesic effects of opioids were absent in GIRK2 null-mutant mice $[159,160]$ or by OPR antagonist [161]. Alcohol exposure augments the opioid's analgesic response by co-activating both OPR and GIRK2 channel activations [161,162]. Unlike the opioid-induced analgesia, the NMDAR-mediated analgesia may occur independently of GIRK2 channels are not modulated by alcohol exposure [162].

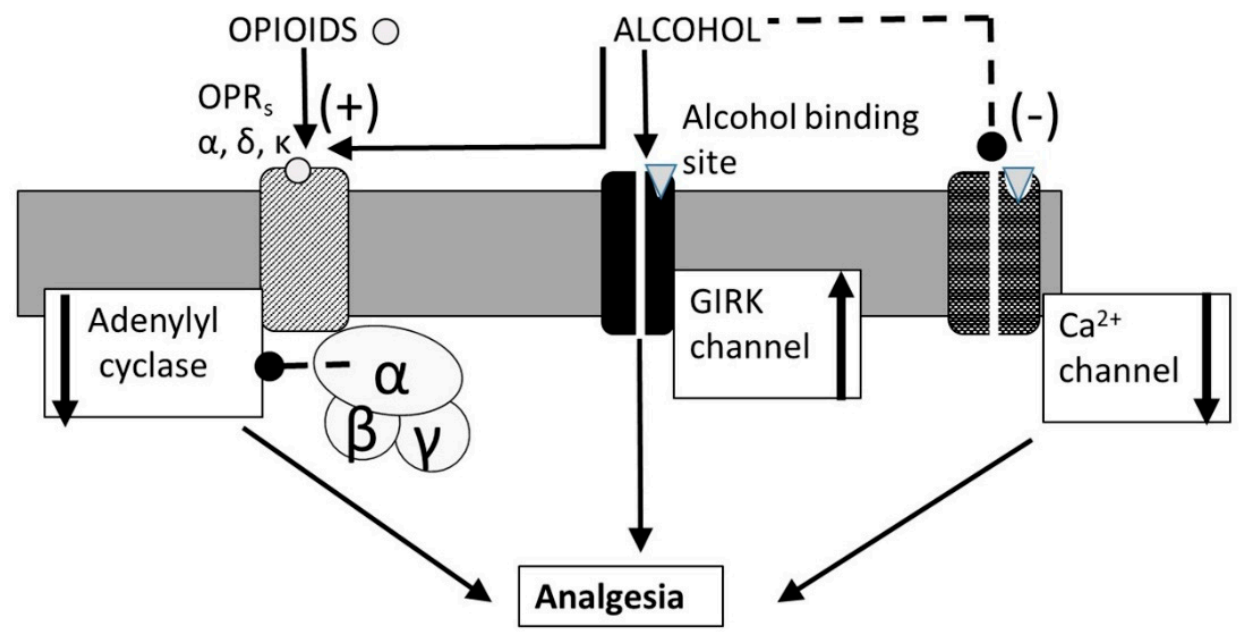

Figure 12. Signal pathways mediating opioid-induced analgesia. Opioids distinctively activates MOR, DOR, and $K O R$, that leads to $G_{i / o}$ protein activation. The activated $G_{i / o}$ protein activates the GIRK channel and inhibits the function of adenylyl cyclase and calcium channels. Alcohol activates the GIRK channel directly and modulates the functions of other target molecules. Non-steroid anti-inflammatory drugs (NSAIDs) induce analgesia in a GIRK channel independent fashion. In weaver mutant mice, GIRK channel activation either by $\mathrm{G}_{\mathrm{i} / \mathrm{o}}$ protein or by alcohol is impaired, and both opioid- and alcohol-induced analgesia is reduced, whereas NSAIDs normally induce analgesia.

Kranzler et al. [163] and Zhang et al. [164] have shown that the A118G variant of the MOR1 (OPRM1) gene may be an obvious candidate mediating alcohol-induced analgesia. A118G carriers experience attenuated pain sensitivity that may alter analgesic responses to alcohol [141]. The A118G or val158met polymorphism of the catechol-O-methyl-transferase (COMT) gene could be a possible link between alcohol's analgesia and reinforcement activities $[165,166]$. The val158met carrier exhibit higher COMT levels, lower $\mathrm{DA}_{\text {ergic }}$ neurotransmission, elevated activation of the MORs $[167,168]$, and suppressed MOR NT response to pain [169]. 
Possible CNS mechanisms underlying the addictive effects of opioids alone or in combination with alcohol are hypothesized in Figure 13. Acute alcohol exposure causes reinforcing (euphoria, red font) and weak analgesia, while acute opioid exposure (blue font) causes strong analgesia (Figure 13A red font). Acute alcohol activates $\mathrm{DA}_{\text {ergic }}$ neurons, thus releasing endogenous opioids (eOPs) that inhibits $\mathrm{GABA}_{\text {ergic }}$ activity either by directly binding to the OPRs or via inhibiting Glu release from the $\mathrm{Glu}_{\text {ergic }}$ neurons [170]. A decrease in GABA disinhibits postsynaptic $\mathrm{DA}_{\mathrm{INT}}$ neurons resulting in an increase in DA release in NAc causing reinforcing and pleasure effects. However, acute exposure to synthetic opioids such as morphine directly activates OPR-signaling, resulting in potent activation of cAMP signaling and ensuing analgesia, with weaker reinforcing [171].

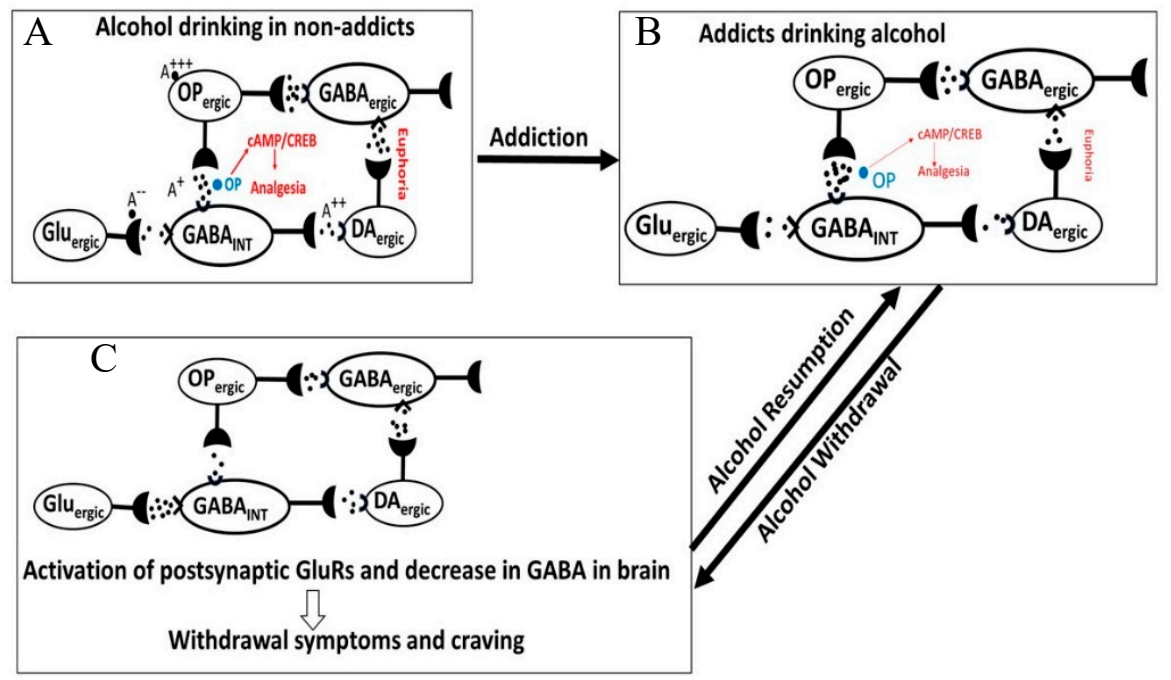

Figure 13. Possible mechanisms underlying the reinforcing and analgesic effects of alcohol exposure. (A) Acute alcohol exposure induces eOP release but inhibits Glu release from Glu $\mathrm{u}_{\text {ergic }}$ neurons, resulting in suppression of $\mathrm{GABA}_{\text {ergic }}$ neurons. Downregulation of $\mathrm{GABA}_{\text {ergic }}$ neurons disinhibits $\mathrm{DA}_{\text {ergic }}$ neurons, resulting in an increase in DA release and ensuing reinforcement. Opioid exposure induces analgesia via cAMP/CREB signaling. (B) In addicted subjects consuming alcohol, $\mathrm{OP}_{\text {ergic }}, \mathrm{Glu}_{\text {ergic }}$ and $\mathrm{GABA}_{\text {ergic }}$ neurons respond like the non-addicted subjects, but $\mathrm{DA}_{\text {ergic }}$ neurons and the analgesic pathway are less responsive. Cumulatively, addicted subjects drinking alcohol exhibited poor opioid-induced analgesia and euphoria. (C) Alcohol abstinence in addicted subjects result in hyperactivity of Glu ergic but downregulation of $\mathrm{GABA}_{\text {ergic }}$ neurons, causing neuronal excitation and the withdrawal symptoms. Alcohol resumption restores opioid's analgesic potency but to a lesser degree, but eOP release is restored.

The addictive effects of alcohol and opioids are mediated by a common addiction pathway (Figure 13B) [172-174]. In alcoholic subjects, alcohol exposure reduces release of eOPs from OP ergic neurons, but activates Glu release from Glu $\mathrm{u}_{\text {ergic }}$ neurons, resulting in an increase in GABA ergic activity and GABA release. As shown in Figure 13C, alcohol withdrawal causes further increase in Glu ergic activity and decrease in $\mathrm{GABA}_{\text {ergic }}$ activity. This results in amplification of the withdrawal symptoms. Alcohol resumption establishes homeostasis by increasing GABA $_{\text {ergic }}$ activity, while Glu $\mathrm{u}_{\text {ergic }}$ activity remains elevated.

Taken together, these observations indicate that alcohol and opioid drugs have numerous common behavioral effects, including sedation, motor depression, and rewarding experiences, possibly related to the effects of alcohol administration on release of eOP peptides $[175,176]$. An increase of eOP peptides increase alcohol consumption that is blocked by nonselective opioid antagonists such as naloxone and naltrexone [177,178]. Possible adverse effects of alcohol on opioids are shown in Figure 14. 


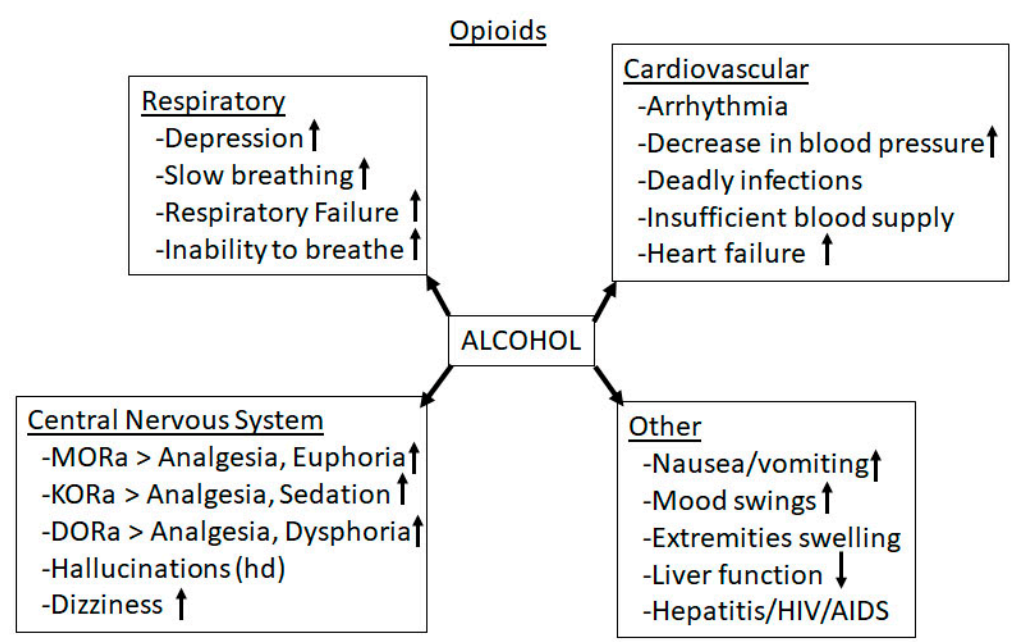

Figure 14. Effects of Alcohol exposure on opioid's pharmacokinetics, cardiovascular function, CNS functions and prenatal effects.

\subsection{Alcohol-Cannabis Interactions}

$\Delta^{9}$-Tetrahydrocannabinol (THC), the main psychoactive component of cannabis [179], elicits its acute effects via the endocannabinoid $(\mathrm{eCB})$ type $1\left(\mathrm{CB}_{1}\right)$ receptor $\left(\mathrm{CB}_{1} \mathrm{R}\right)$ [180]. THC has been linked to the rewarding aspects and cognitive impairments of cannabis (Figure 15). 2-Arachidonoylglycerol (2-AG), produced by diacylglycerol lipase (DAGL) in $\mathrm{DA}_{\text {ergic }}$ VTA neurons [181], acts on $\mathrm{CB}_{1}$ Rs on nearby $\mathrm{Glu}_{\text {ergic }}$ and $\mathrm{GABA}_{\text {ergic }}$ terminals. $\mathrm{CB}_{1}$ Rs robustly inhibit GABA inputs onto VTA DA cells. $\mathrm{CB}_{1}$ Rs are also localized on Glu $\mathrm{u}_{\text {ergic }}$ terminals synapsing on VTA DA neurons where eCBs mediate retrograde suppression of excitation. Thus, $\mathrm{eCBs}$ fine-tune the activity of the mesolimbic DA projections through modulating both excitatory and inhibitory signaling [182]. THC exposure disrupts the eCB retrograde signaling system and produces complex, diverse and potentially long-term effects on the $\mathrm{DA}_{\text {ergic }}$ system including increase in nerve firing and DA release in response to acute THC. However, $\mathrm{DA}_{\text {ergic }}$ blunting may be associated with long-term use [183,184].

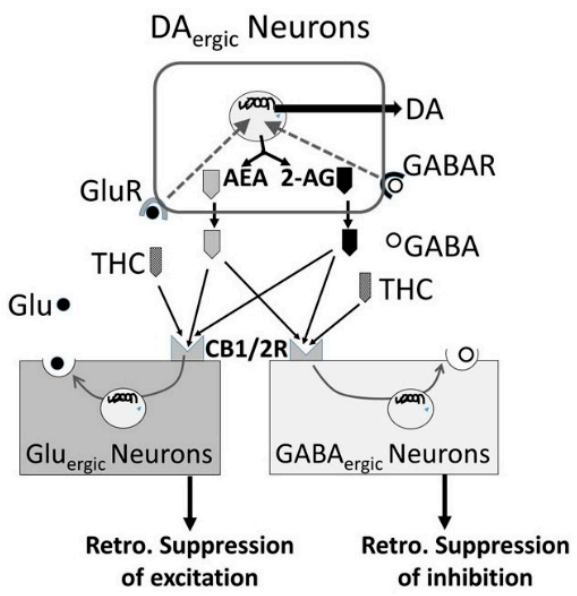

Figure 15. Schematic description the endocannabinoid receptor signaling. Endogenous endocannabinoids, $\mathrm{N}$-arachidonoy-lethanolamine (anandamide or AEA) and 2-arachido-noylglycerol (2-AG) released by the VTA neurons, bind to CB1 and CB2 receptors on Glu $\mathrm{u}_{\text {ergic }}$ and $\mathrm{GABA}_{\text {ergic }}$ neurons, resulting in release of Glu and GABA, respectively. Glu and GABA bind to their respective receptors on $\mathrm{DA}_{\text {ergic }}$ neurons and induce DA release. Cannabis such as THC compete with ARA and 2-AG for CB1 (AEA >> 2-AG) and $\mathrm{CB} 2(\mathrm{AEA} \approx 2-\mathrm{AG})$ receptors and disrupts normal endocannabinoid retrograde signaling from $\mathrm{DA}_{\text {ergic }}$ neurons. 
Alcohol and cannabis, being neuro-inhibitory agents, share many behavioral abnormalities such as euphoria, analgesia, sedation, hypothermia, cognitive and motor dysfunctions, etc. [185] Therefore, combination of alcohol and marijuana in occasional cannabis users may additively alter the magnitude of cognitive and motor impairments [186,187]. However, chronic cannabis use may develop tolerance to the impairing effects of cannabis and/or alcohol. Studies have shown that approximately $58 \%$ of adolescent drinkers also use cannabis [188], contributing to frequent comorbidity between alcohol and cannabis use disorders [189]. Figure 16 [190] shows 30-day trends in alcohol and cannabis use prevalence (1976-2011) among high school students. Plots 1 and 2 show percentage of students using alcohol and cannabis, respectively, for the last 30 days, while plots 3 regular cannabis uses accompanied by alcohol use some time and plot 4 shows cannabis use was almost always associated with alcohol use.

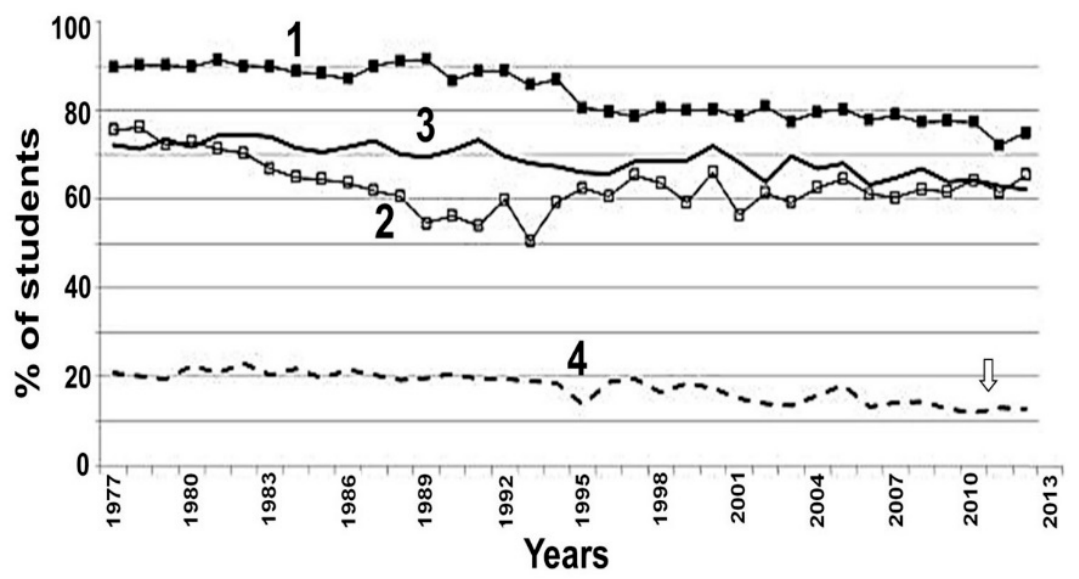

Figure 16. Prevalence of alcohol and cannabis use among high school students is shown from 1976-2011. Plots 1 and 2 show percentage of students using alcohol and cannabis, respectively, for last 30 days, while plots 3 shows regular cannabis use accompanied with alcohol use some time. Plot 4 shows the number of students in which cannabis use was almost always associated with alcohol use. [Data from [190] were used in this plot.

Figure 16 suggests that a sizable proportion of US high school seniors used a combination of alcohol and cannabis in social use situations. Alcohol and cannabis use during adolescence is of concern because the introduction of drug combinations early may disrupt healthy brain development [191,192]. Studies have shown that the hippocampus (a region associated with learning and memory formation [193]) may be particularly vulnerable to structural damage caused by heavy alcohol and/or cannabis use, especially during adolescence. Aloi et al. [194] have demonstrated differential patterns of dysfunction associated with alcohol use disorder (AUD) and cannabis use disorder (CUD) symptoms. Elevated severity of AUD symptoms was associated with (i) an increased amygdala response to positive relative to neutral stimuli and (ii) a decreased responses associated with behavioral inhibition and executive attention during incongruent and congruent trials, while elevated CUD symptomatology was associated with increased responses in the posterior cingulate cortex, precuneus, and inferior parietal lobule for incongruent relative to congruent and view trials. This suggests that correlates of AUD symptomatology may differ from those of CUD symptomatology. Therefore, a combination of AUD and CUD may additively cause greater brain damage than AUD or CUD individually as summarized in Figure 17.

Earlier studies [195-197] have identified mechanistic links between the effects of alcohol and cannabinoids, both enhanced DA levels in the NAc by activating DA ergic neurons in the VTA from which the mesoaccumbal DA-mediated pathway originates. Hungund et al. [198] showed that alcohol did not cause the release of DA in $\mathrm{CB}_{1}^{-/-}$mice or SR141716A, a selective cannabinoid receptor antagonist, administered wild-type mice. Cohen et al. [199] showed that SR141716A reduced alcohol consumption, possibly via reducing DA release in the NAc in mice. These results strongly suggest that administration of cannabis and alcohol may additively enhance DA release the NAc. Guillot et al. [200] 
showed that, among people using cannabis and alcohol, the interplay between social anxiety and coping-oriented motives for using one substance (such as cannabis or alcohol) may pose difficulties in refraining from other substances such as alcohol or tobacco). Therefore, it is important to tailor multi-substance treatments to specific needs when a single-substance intervention may not be effective.

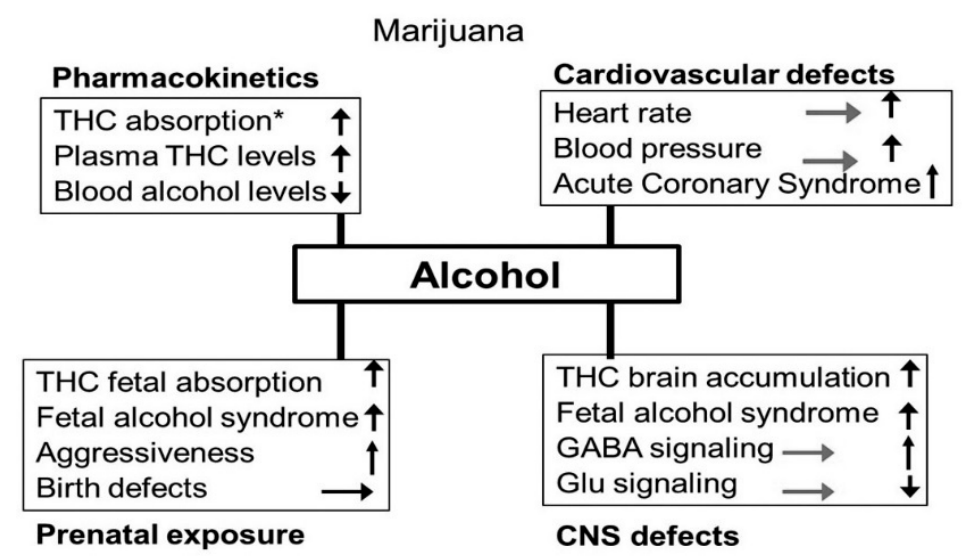

Figure 17. Effects of alcohol exposure on cannabis's pharmacokinetics, cardiovascular function, CNS functions and prenatal effects.

Although the molecular basis of alcohol-cannabis interaction is not yet known, recent studies have proposed epigenetic mechanisms (nuclear factors, histone modifications, and DNA methylation) to be important in determining consequences of the interaction [201-203]. A critical clue for alcohol-cannabis interaction was provided by the following observation: CB1 receptor knockout mice or those treated with CB1 antagonist exhibited markedly reduced voluntary alcohol consumption, possibly due to lack alcohol-induced DA release in the NAc [204]. Subbanna et al. [205] reported that post-natal alcohol exposure induced neonatal neurodegeneration possibly by enhancing CB1 exon1 activity through upregulated histone H4K8 acetylation and downregulated H3K9 methylation. Another study showed that perinatal alcohol exposure impaired DNA methylation through downregulation of DNA methyl transferases DNMT1 and DNMT3A in the neonatal brain and that such deficiencies were absent in CB1 receptor null mice [206]. Taken together, these reports suggest the potential of epigenetic overlap between alcohol and cannabis activities. Figure 18 summarizes the epigenetic mechanisms of alcohol and cannabinoid activity and possible overlaps between the two substances at the epigenetic level [207,208].

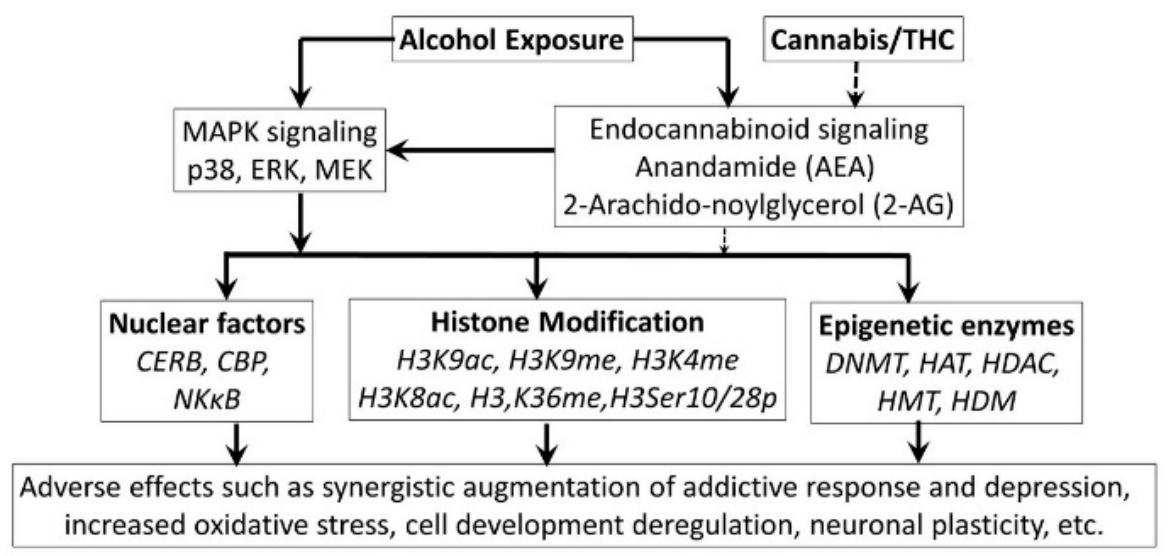

Figure 18. Possible epigenetic mechanisms for alcohol—cannabis interactions. Alcohol and cannabis both modulate CB1 and CB2 receptors, resulting in activation of the MAPK signaling pathways, that further activates (i) nuclear factors CREB and NF- $k B$, (ii) histone modifications, and (iii) DNA methylation mediated by the epigenetic enzymes. This leads to altered gene expression and cell functionality through apoptosis, oxidative stress, plasticity or immuno-modulation. 


\subsection{Alcohol-GHBA Interactions}

GHB is a natural sedative with the potential to be used as a recreational drug $[209,210]$. The popularity of GHB as a drug of abuse has grown recently [211]. Alcohol has been shown to enhance the sedative effect of GHB in humans and animals [212,213]. Co-administration of GHB and alcohol induces sedation stronger than the sum of the sedation induced by the individual substances [214], possibly due to a pharmacokinetic interaction resulting in an increased concentration at the site of action (Figure 19).

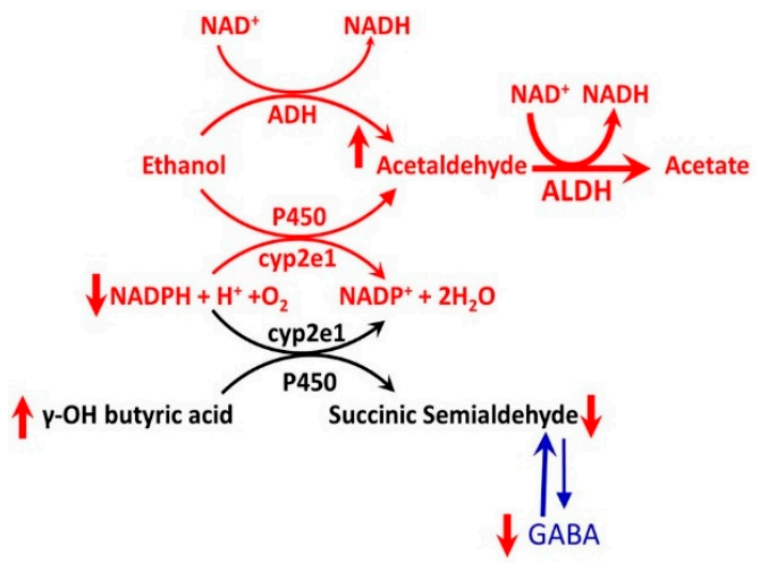

Figure 19. Pharmacokinetic mechanism of alcohol-GHB interaction. GHB is primarily metabolized to succinic semialdehyde (SSA) by a P450 mediated $\mathrm{NAD}(\mathrm{P})^{+}$-linked oxidation catalyzed by GHB dehydrogenase (GHBD). SSA is further metabolized to succinic acid, a citric acid cycle substrate. In case of alcohol-GHB co-exposure, alcohol competes with GHB for the enzyme's binding sites, resulting in a decrease in GHB metabolism. However, for exogenously administered GHB, it is unclear whether co-administration with alcohol results in increased GHB or alcohol plasma concentrations.

To understand the effects of alcohol on the pharmacokinetics of GHB, it is important to understand alcohol's interaction with the metabolic system. Studies have shown that, at lower alcohol concentrations, only about $10 \%$ of the consumed alcohol undergoes CYP-mediated first-pass metabolism in liver. Since alcohol and GBH compete for CYP2E1 (GHBD), alcohol, depending on its concentration, reduces GBH degradation and ensuing increase in its blood concentrations [215]. Chronic, heavy alcohol consumption induces the activity of CYP2E1, resulting in a decrease in GHB concentrations. The adverse effects related to GHB ingestion are shown in Figure 20 [216]. Overall adverse effects depend on the variability among users and the inherent variability in street manufacturing [217]. This makes GHB a highly dangerous drug to consume. It exhibits a steep dosage-response curve, thus, exceeding the intoxicating dose can result in severe adverse effects occurring within 15 minutes of ingestion of GHB [218,219].

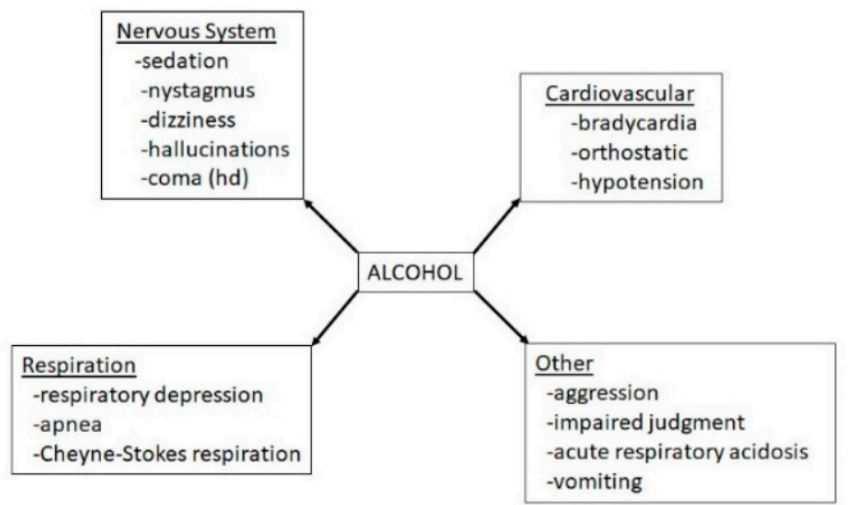

Figure 20. Effects of alcohol exposure on GHBA's pharmacokinetics, cardiovascular function, CNS functions and prenatal effects. 


\section{Conclusions}

Co-abuse of alcohol with drugs of abuse (psychostimulants (cocaine, METH and nicotine) and inhibitors (opioids, cannabis and GHBA) and medications) is a serious health problem the society faces today. People abuse multiple drugs possibly due to the perception of potentiated euphoric and pleasure effects and decreased adverse subjective effects. The negative consequences of alcohol and psychostimulant co-abuse may include a decrease in antioxidant enzymes, disruption of learning and memory processes, cerebral hypo-perfusion, neurotransmitters depletion as well as potentiated drug-seeking behavior. As summarized in Figure 21, alcohol activates inhibitory GABA $\mathrm{ergic}_{\text {and }}$ $\mathrm{OP}_{\text {ergic }}$ neurons, but inhibits excitatory $\mathrm{Glu}_{\text {ergic }}$ neurons. Thus, alcohol additively or synergistically augments inhibitory signaling by opioids, cannabis and GHB, but suppresses stimulatory signaling by cocaine, METH and nicotine. Alcohol may also modify the liver CYP enzymes, thus modifying the drugs plasma concentrations. Taken together, alcohol may modify both the pharmacokinetics and pharmacodynamics of co-abused drugs. Therefore, alcohol-drug interaction must be considered when developing alcoholism therapy.

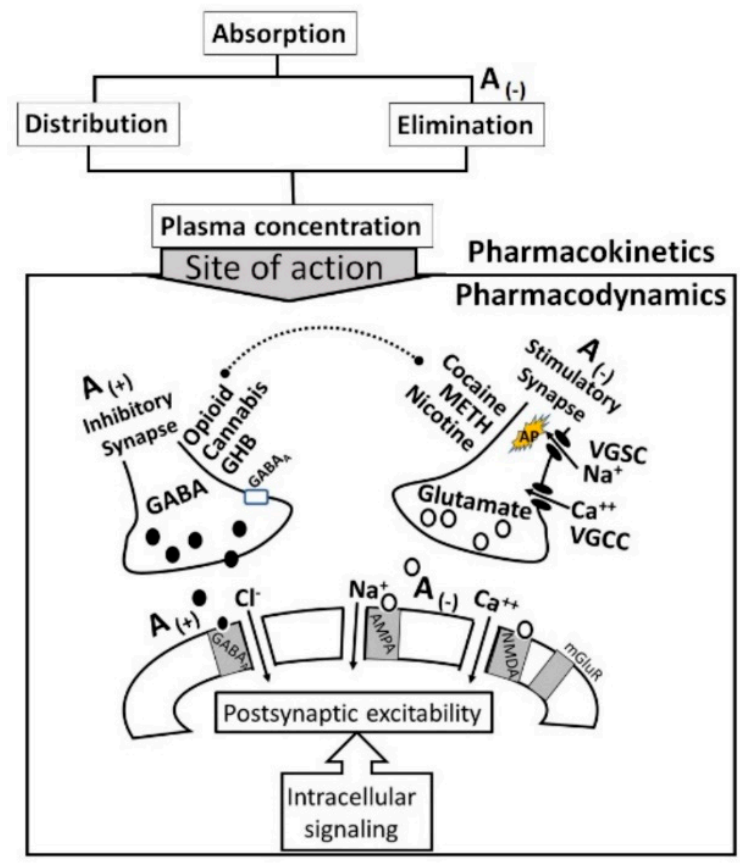

Figure 21. Proposed mechanisms underlying alcohol's interaction with co-abused drugs. Alcohol (referred as alcohol in this article) is rapidly absorbed and distributed. It is metabolized to acetaldehyde by $\mathrm{ADH}$ and CYP enzymes, then to acetate by ALDH. In this process, alcohol competes with the co-administered drugs and suppresses their elimination, thus increasing the drug's plasma concentration and altering its pharmacokinetics (increase in $\mathrm{C}_{\max }$ and AUC, decrease in CL). Chronic alcohol exposure activates the liver CYP enzymes, resulting in a decrease in the drug's plasma concentrations, with a decrease in its efficacy. Alcohol, in addition to altering pharmacokinetics of a drug, also alter its pharmacodynamics by activating $\mathrm{GABA}_{\text {ergic }}$ and $\mathrm{OP}_{\text {ergic }}$ presynaptic neurons $\left(\mathrm{A}_{(+)}\right.$, but inhibiting Glu $\mathrm{ergic}_{\text {ic }}$ presynaptic neurons $\left(\mathrm{A}_{(-)}\right)$. Post-synoptically, alcohol activates $\mathrm{GABA}_{\mathrm{A}} \mathrm{R}$ mediated influx of $\mathrm{Cl}^{-}$ ions, but inhibits AMPAR-mediated $\mathrm{Na}^{+}$ions and NMDAR-mediated $\mathrm{Ca}^{2+}$ ions, resulting in reduced excitability via IPSP. Therefore, alcohol may augment the effects of inhibitory drugs (opioids, cannabis and GHB) but suppress the effects of excitatory drugs (cocaine, METH or nicotine). Chronic alcohol exposure may have opposite effects not shown in this figure. Abbreviations: $\mathrm{A}_{(+)}$: positive alcohol effects, $\mathrm{A}_{(-)}$: negative alcohol effects, VGSE: voltage-gated sodium ion $\left(\mathrm{Na}^{+}\right)$channels that may be attenuated by alcohol's IPSP, VGCC: voltage-gated calcium ion $\left(\mathrm{Ca}^{2+}\right)$ channels that may be attenuated by alcohol's IPSP, GABA $\mathrm{A}$ mediated $\mathrm{Cl}^{-}$channels that may be additively/synergistically activated by alcohol's IPSP, inhibitory neurotransmitters, excitatory. neurotransmitters, $\angle \mathrm{AP}$ action potential. 
Conflicts of Interest: The author declares no conflict of interest.

\section{Abbreviations}

2-AG

5-HT

$\mathrm{A}_{(+)}$

$\mathrm{A}_{(-)}$

AA

AC

$\mathrm{ACh}$

$\mathrm{ACh}_{\text {ergic }}$

$\mathrm{ADH}$

ALDH

AMPA

AUC

AUD

CAMP

CL

$\mathrm{C}_{\max }$

COMT

COX

CYP

DA

DA

DAG

DAGL

DAR1

DAT

DOR

DPDEP

EAA

eCB

eOP

ERK

GABA

$\mathrm{GABA}_{\mathrm{B}} \mathrm{R}$

$\mathrm{GABA}_{\text {ergic }}$

GHB

GHBD

GIRK

Glu

Glu ergic

Gly

$\mathrm{IP}_{3}$

KOR

LDTg

LPS

METH

mGluR2/3

MOR

NAc

nAChR

NAPQI
2-Arachidonoylglycerol

Serotonin

alcohol's +ve effects

alcohol's _ ve effects

arachidonic acid

adenylyl cyclase

Acetylcholine

ACh releasing neurons

alcohol dehydrogenase

acetaldehy6de dehydrogenase

$\alpha$-amino-3-hydroxy-5-methyl-4-isoxazolepropionic acid

area under curve

alcohol use disorder

cyclic adenosine monophosphate

clearance

maximum concentration

catechol-O-methyl-transferase

Cyclooxygenase

cytochrome P450

Dopamine

dopamine\}

Diacylglycerol

diacylglycerol lipase

dopamine receptor 1

dopamine transporter

delta OPRs

D-Pen ${ }^{2}$, D-Pen ${ }^{5}$ enkephalin, DOR agonist

excitatory amino acids

Endocannabinoid

endogenous opioids

extracellular-signal-regulated kinase

$\gamma$-aminobutyric acid

GABA B receptor

GABA releasing neurons

$\gamma$-hydroxybutyric acid

GHB dehydrogenase

$\mathrm{G}$ protein-coupled inwardly-rectifying potassium channels

Glutamate

glutamate releasing neurons

Glycine

inositol trisphosphate

kappa OPRs

laterodorsal tegmental nucleus

Lipopolysaccharide

Methamphetamine

metabolic Glu receptors 2/3

mu OPRs

nucleus accumbens

nicotinic ACh receptor

$\mathrm{N}$-acetyl-p-benzoquinone imine 


$\begin{array}{ll}\text { NE } & \text { Noradrenaline } \\ \text { NMDA } & \text { N-methyl-D-Aspartate receptors } \\ \text { OP } & \text { Opioid } \\ \text { OPR } & \text { opioid receptors } \\ \text { OPRM1 } & \text { A118G variant of the MOR1 } \\ \text { PIP2 } & \text { poly inositol diphosphate } \\ \text { pptg } & \text { pedunculopontine tegmental nucleus } \\ \text { SERT } & \text { serotonin transporter } \\ \text { sOP } & \text { synthetic opioids } \\ \text { SSA } & \text { succinic semialdehyde } \\ \text { T } & \text { elimination half-life } \\ \text { THC } & \Delta^{9} \text {-Tetrahydrocannabinol } \\ t_{\text {max }} & \text { time to Cmax } \\ \text { TMU } & 1,3,7-\text { trimethyluric acid } \\ \text { U50488H } & \text { KOR agonist } \\ \text { VGSC } & \text { voltage gated sodium ion }\left(\mathrm{Na}^{+}\right) \text {channel } \\ \text { VGCC } & \text { voltage gated calcium ion }\left(\mathrm{Ca}^{2+}\right) \text { channel } \\ \text { VTA } & \text { ventral tegmental area } \\ \alpha 7 \text { and } \alpha 4 \beta 2 & \text { nicotinic receptor subtypes }\end{array}$

\section{References}

1. Peacock, A.; Leung, J.; Larney, S. Global statistics on alcohol, tobacco and illicit drug use: 2017 status report. Addiction 2018, 113, 1905-1926. [CrossRef] [PubMed]

2. World Health Organization. Global Status Report on Alcohol and Health 2018; World Health Organization: Geneva, Switzerland, 2018.

3. Kaufman, E. The abuse of multiple drugs. I. Definition, classification, and extent of problem. Am. J. Drug Alcohol Abus. 1976, 3, 279-292. [CrossRef]

4. Karjalainen, K.; Kuussaari, K.; Kataja, K.; Tigerstedt, C.; Hakkarainen, P. Measuring Concurrent Polydrug Use in General Populations: A Critical Assessment. Eur. Addict. Res. 2017, 23, 163-169. [CrossRef] [PubMed]

5. Pakula, B.; McDonald, S.; Stockwell, Y. Simultaneous use of alcohol and cocaine: A qualitative investigation. J. Subst. Use 2009, 14, 101-112. [CrossRef]

6. Higgins, S.T.; Sigmon, S.C.; Wong, C.J.; Heil, S.H.; Badger, G.J.; Donham, R.; Dantona, D.L.; Anthony, S. Community reinforcement therapy for cocaine-dependent outpatients. Arch. Gen. Psychiatry 2003, 60, 1043-1052. [CrossRef] [PubMed]

7. Budd, R.D. Cocaine Abuse and Violent Death. Am. J. Drug Alcohol Abus. 1989, 15, 375-382. [CrossRef]

8. Marzuk, P.M.; Tardiff, K.; Leon, A.C.; Stajic, M.; Morgan, E.B.; Mann, J.J. Prevalence of Recent Cocaine Use Among Motor Vehicle Fatalities in New York City. JAMA 1990, 263, 250-256. [CrossRef] [PubMed]

9. Dani, J.A.; Harris, R.A. Nicotine addiction and comorbidity with alcohol abuse and mental illness. Nat. Neurosci. 2005, 8, 1465-1470. [CrossRef] [PubMed]

10. Patrick, M.E.; Schulenberg, J.E.; O'malley, P.M.; Maggs, J.L.; Kloska, D.D.; Johnston, L.D.; Bachman, J.G. Age-Related Changes in Reasons for Using Alcohol and Marijuana from Ages 18 to 30 in a National Sample. Psychol. Addict. Behav. 2011, 25, 330-339. [CrossRef] [PubMed]

11. Althobaiti, Y.; Sari, Y. Alcohol Interactions with Psychostimulants: An Overview of Animal and Human Studies. J. Addict. Res. Ther. 2016, 7, 281. [CrossRef] [PubMed]

12. Lemstra, M.; Bennett, N.R.; Neudorf, C.; Kunst, A.; Nannapaneni, U.; Warren, L.M.; Kershaw, T.; Scott, C.R. A meta-analysis of marijuana and alcohol use by socio-economic status in adolescents aged 10-15 years. Can. J. Public Health 2008, 99, 172-177. [PubMed]

13. Thai, D.; Dyer, J.E.; Benowitz, N.L.; Haller, C.A. GHB and Ethanol Effects and Interactions in Humans. J. Clin. Psychopharmacol. 2006, 26, 524-529. [CrossRef] [PubMed]

14. Mason, W.A.; Chmelka, M.B.; Howard, B.K.; Thompson, R.W. Comorbid Alcohol and Cannabis Use Disorders Among High-Risk Youth at Intake into Residential Care. J. Adolesc. Health 2012, 53, 350-355. [CrossRef] [PubMed] 
15. Rasch, R.F.; Weisen, C.A.; MacDonald, B.; Wechsberg, W.M.; Perritt, R.; Dennis, M.L. Patterns of HIV risk and alcohol use among African-American crack abusers. Drug Alcohol Depend. 2000, 58, 259-266. [CrossRef]

16. George, S.; Rogers, R.D.; Duka, T. The acute effect of alcohol on decision making in social drinkers. Psychopharmacology 2005, 182, 160-169. [CrossRef] [PubMed]

17. Fisher, J.C.; Bang, H.; Kapiga, S.H. The association between HIV infection and alcohol use: A systematic review and meta-analysis of African studies. Sex. Transm. Dis. 2007, 34, 856-863. [CrossRef] [PubMed]

18. Arasteh, K.; Des Jarlais, D.C.; Perlis, T.E. Alcohol and HIV sexual risk behaviors among injection drug users. Drug Alcohol Depend. 2008, 95, 54-61. [CrossRef] [PubMed]

19. Van Tieu, H.; Koblin, B.A. HIV, alcohol, and non-injection drug use. Curr. Opin. HIV AIDS 2009, 4, 314-318. [CrossRef] [PubMed]

20. Stinson, F.S.; Grant, B.F.; Dawson, D.A.; Ruan, W.J.; Huang, B.; Saha, T. Comorbidity between DSM-IV alcohol and specific drug use disorders in the United States: Results from the National Epidemiologic Survey on Alcohol and Related Conditions. Alcohol Res. Health 2006, 29, 94-107.

21. Levine, B.; Green, D.; Smialek, J. The Role of Ethanol in Heroin Deaths. J. Forensic Sci. 1995, 40, 808-810. [CrossRef] [PubMed]

22. Hickman, M.; Lingford-Hughes, A.; Bailey, C.; Macleod, J.; Nutt, D.; Henderson, G. Does alcohol increase the risk of overdose death: The need for a translational approach. Addiction 2008, 103, 1060-1062. [CrossRef] [PubMed]

23. Fraser, A.G. Pharmacokinetic interactions between alcohol and other drugs. Clin. Pharmacokinet. 1997, 33, 79-90. [CrossRef] [PubMed]

24. Moore, N.; Pollack, C.; Butkerait, P. Adverse drug reactions and drug-drug interactions with over-the-counter NSAIDs. Ther. Clin. Risk Manag. 2015, 11, 1061-1075. [PubMed]

25. Zakhari, S. Overview: How Is Alcohol Metabolized by the Body? Alcohol Res. Health 2006, 29, $245-255$. [PubMed]

26. Edenberg, H.J. The Genetics of Alcohol Metabolism: Role of Alcohol Dehydrogenase and Aldehyde Dehydrogenase Variants. Alcohol Res. Health 2007, 30, 5-13. [PubMed]

27. Niemelä, O.; Parkkila, S.; Pasanen, M.; Limuro, Y.; Bradford, B.; Thurman, R.G. Early alcoholic liver injury: Formation of protein adducts with acetaldehyde and lipid peroxidation products, and expression of CYP2E1 and CYP3A. Alcohol. Clin. Exp. Res. 1998, 22, 2118-2124. [CrossRef] [PubMed]

28. Flockhart, D.A. Drug Interactions: Cytochrome P450 Drug Interaction Table. Indiana University School of Medicine. 2007. Available online: https:/ / drug-interactions.medicine.iu.edu (accessed on 15 November 2018).

29. Bibi, Z. Role of P450 in drug interactions. Nutr. Metab. 2008, 5, 27. [CrossRef] [PubMed]

30. Chan, L.N.; Anderson, G.D. Pharmacokinetic and Pharmacodynamic Drug Interactions with Ethanol (Alcohol). Clin. Pharmacokinet. 2014, 53, 1115-1136. [CrossRef] [PubMed]

31. Bruce, R.D.; Altice, F.L.; Fried, G.H. Pharmacokinetic drug interactions between drugs of abuse and antiretroviral medications: Implications and management for clinical practice. Exp. Rev. Clin. Pharm. 2008, 1, 115-127. [CrossRef] [PubMed]

32. Parker, R.B.; Laizurs, S.C. The Effect of Ethanol on Oral Cocaine Pharmacokinetics Reveals an Unrecognized Class of Ethanol-Mediated Drug Interactions. Drug Metab. Dispos. 2010, 38, 317-322. [CrossRef] [PubMed]

33. Pan, W.-J.; Hedaya, M.A. Cocaine and Alcohol Interactions in the Rat: Effect on Cocaine Pharmacokinetics and Pharmacodynamics. J. Pharm. Sci. 1999, 88, 459-467. [CrossRef] [PubMed]

34. Yao, D.; Shi, X.; Wang, L.; Gosnell, B.A.; Chen, C. Characterization of Differential Cocaine Metabolism in Mouse and Rat through Metabolomics-Guided Metabolite Profiling. Drug Metab. Dispos. 2013, 41, 79-88. [CrossRef] [PubMed]

35. Patrick, K.S.; Straughn, A.B.; Minhinnett, R.R.; Yeatts, A.E.; DeVane, C.L.; Malcolm, R.; Janis, G.C.; Markowitx, J.S. Influence of ethanol and gender on methylphenidate pharmacokinetics and pharmacodynamics. Clin. Pharmacol. Ther. 2007, 81, 346-353. [CrossRef] [PubMed]

36. Li, B.; Wang, Y.; Zhang, Y.; Liu, M. Effects of Ethanol on the Toxicokinetics of Methamphetamine in Rabbits. Iran. J. Pharm. Res. 2014, 13, 329-336. [PubMed]

37. Adir, J.; Wildfeur, W.; Miller, R.P. Effect of Ethanol Pretreatment on the Pharmacokinetics of Nicotine in Rats. J. Pharmacol. Exp. Ther. 1980, 212, 274-279. [PubMed]

38. Rose, J.E.; Brauer, L.H.; Behm, F.M. Psychopharmacological interactions between nicotine and ethanol. Nicotine Tobacco Res. 2004, 6, 133-144. [CrossRef] [PubMed] 
39. Ferguson, C.S.; Miksys, S.; Palmour, R.M.; Tyndale, R.F. Differential Effects of Nicotine Treatment and Ethanol Self-Administration on CYP2A6, CYP2B6 and Nicotine Pharmacokinetics in African Green Monkeys. J. Pharm. Exp. Ther. 2012, 343, 628-637. [CrossRef] [PubMed]

40. Toennes, S.W.; Schneider, K.; Kauert, G.F.; Wunder, C.; Moeller, M.R.; Theunissen, E.L.; Ramaekers, J.G. Influence of ethanol on cannabinoid pharmacokinetic parameters in chronic users. Anal. Bioanal. Chem. 2011, 400, 145-152. [CrossRef] [PubMed]

41. Toennes, S.W.; Schneider, K.; Wunder, C.; Kauert, G.F.; Moeller, M.R.; Theunissen, E.L.; Ramaekers, J.C. Influence of Ethanol on the Pharmacokinetic Properties of $\Delta^{9}$-Tetrahydrocannabinol in Oral Fluid. J. Anal. Toxicol. 2013, 37, 152-158. [CrossRef] [PubMed]

42. Hartman, R.L.; Brown, T.L.; Milavetz, G.; Spurgin, A.; Gorelick, D.A.; Gaffney, G.; Huestis, M.A. Controlled cannabis vaporizer administration: Blood and plasma cannabinoids with and without alcohol. Clin. Chem. 2015, 61, 850-869. [CrossRef] [PubMed]

43. Lukas, S.E.; Oroczo, S. Ethanol increases plasma Delta (9)-tetrahydrocannabinol (THC) levels and subjective effects after marihuana smoking in human volunteers. Drug Alcohol Depend. 2001, 64, 143-149. [CrossRef]

44. Dorian, P.; Sellers, E.M.; Reed, K.L. Amitriptyline and ethanol: Pharmacokinetic and pharmacodynamic interaction. Eur. J. Clin. Pharmacol. 1983, 25, 325-331. [CrossRef] [PubMed]

45. Morgan, D.J.; McLean, A.J. Clinical pharmacokinetic and pharmacodynamic considerations in patients with liver disease. Clin. Pharmacokinet. 1995, 29, 370-391. [CrossRef] [PubMed]

46. Hoyovadillo, C.; Mandema, J.W.; Danhof, M. Pharmacodynamic interaction between midazolam and a low dose of ethanol in vivo. Life Sci. 1995, 57, 325-333. [CrossRef]

47. Allan, A.M.; Harris, R.A. Acute and chronic ethanol treatments alter GABA receptor-operated chloride channels. Pharmacol. Biochem. Behav. 1987, 27, 665-670. [CrossRef]

48. Wan, F.J.; Berton, F.; Madamba, S.G.; Francesconi, W.; Siggins, G.R. Low ethanol concentrations enhance GABAergic inhibitory postsynaptic potentials in hippocampal pyramidal neurons only after block of GABAB receptors. Proc. Natl. Acad. Sci. USA 1996, 93, 5049-5054. [CrossRef] [PubMed]

49. Roberto, M.; Madamba, S.G.; Moore, S.D.; Tallent, M.K.; Siggins, G.R. Ethanol increases GABAergic transmission at both pre- and postsynaptic sites in rat central amygdala neurons. Proc. Natl. Acad. Sci. USA 2003, 100, 2053-2058. [CrossRef] [PubMed]

50. Cross, S.J.; Lotfipour, S.; Leslie, F.M. Mechanisms and genetic factors underlying co-use of nicotine and alcohol or other drugs of abuse. Am. J. Drug Abus. 2017, 43, 171-185. [CrossRef] [PubMed]

51. Spitz, M.; Amos, C.I.; Dong, Q.; Lin, J.; Wu, X. The CHRNA5-A3 region on chromosome 15q24-25.1 is a risk factor both for nicotine dependence and for lung cancer. J. Natl. Cancer Inst. 2008, 100, 1552-1556. [CrossRef] [PubMed]

52. Bierut, L.J. Nicotine dependence and genetic variation in the nicotinic receptors. Drug Alcohol Depend. 2009, 104, S64-S69. [CrossRef] [PubMed]

53. Wang, J.C.; Grucza, R.; Cruchaga, C.; Hinrichs, A.L.; Bertelsen, S.; Budde, J.P.; Fox, L.; Goldstein, E.; Reyes, O.; Saccone, N.; et al. Genetic variation in the CHRNA5 gene affects mRNA levels and is associated with risk for alcohol dependence. Mol. Psychiatry 2009, 14, 501-510. [CrossRef] [PubMed]

54. Li, M.D.; Xu, Q.; Lou, X.Y.; Payne, T.J.; Niu, T.; Ma, J.Z. Association and interaction analysis of variants in CHRNA5/CHRNA3/CHRNB4 gene cluster with nicotine dependence in African and European Americans. Am. J. Med. Genet. B Neuropsychiatr. Genet. 2010, 153B, 745-756. [PubMed]

55. Mihalak, K.B.; Carroll, F.I.; Luetje, C.W. Varenicline is a partial agonist at alpha4beta2 and a full agonist at alpha7 neuronal nicotinic receptors. Mol. Pharmacol. 2006, 70, 801-805. [CrossRef] [PubMed]

56. Erwin, B.L.; Slaton, R.M. Varenicline in the treatment of alcohol use disorders. Ann. Pharmacother. 2014, 48, 1445-1455. [CrossRef] [PubMed]

57. Narahashi, T.; Aistrup, G.L.; Marszalec, W.; Nagata, K. Neuronal nicotinic acetylcholine receptors: A new target site of ethanol. Neurochem. Int. 1999, 35, 131-141. [CrossRef]

58. Li, M.D.; Burmeister, M. New insights into the genetics of addiction. Nature Rev. Genet. 2009, 10, $225-231$. [CrossRef]

59. Hearn, W.L.; Flynn, D.D.; Hime, G.W.; Rose, S.; Cofino, J.C.; Mantero-Atienza, E.; Wetli, C.V.; Mash, D.C. Cocaethylene: A Unique Cocaine Metabolite Displays High Affinity for the Dopamine Transporter. J. Neurochem. 1991, 56, 698-701. [CrossRef] [PubMed] 
60. Robinson, J.E.; Chen, M.; Stamatakis, A.M. Levetiracetam Has Opposite Effects on Alcohol- and Cocaine-Related Behaviors in C57BL/6J Mice. Neuropsychopharmacology 2013, 38, 1322-1333. [CrossRef] [PubMed]

61. McBride, W.J.; Murphy, J.M.; Ikemoto, S. Localization of brain reinforcement mechanisms: Intracranial self-administration and intracranial place-conditioning studies. Behav. Brain Res. 1999, 101, 129-152. [CrossRef]

62. Wise, R.A. Ventral tegmental glutamate: A role in stress-, cue-, and cocaine-induced reinstatement of cocaine-seeking. Neuropharmacology 2009, 56 (Suppl. 1), S174-S176. [CrossRef] [PubMed]

63. Morikawa, H.; Morrisett, R.A. Ethanol action on dopaminergic neurons in the ventral tegmental area: Interaction with intrinsic ion channels and neurotransmitter inputs. Int. Rev. Neurobiol. 2009, 91, 235-288.

64. Stuber, G.D.; Hopf, F.W.; Tye, K.M. Neuroplastic alterations in the limbic system following cocaine or alcohol exposure. Curr. Top. Behav. Neurosci. 2010, 3, 3-27. [PubMed]

65. Singh, A.K. Critical Review of Alcohol, Alcoholism and the Withdrawal Symptoms I. Mechanisms of Addiction and the Withdrawal Syndrome. Arch. Addict. Rehab. 2017, 1, 11-30.

66. Roberto, M.; Varodavan, F. Synaptic Targets: Chronic Alcohol Actions. Neuropharmacology 2017, 122, 85-99. [CrossRef] [PubMed]

67. Dobbs, L.K.; Mark, G.P. Comparison of Systemic and Local Methamphetamine Treatment on Acetylcholine and Dopamine Levels in the Ventral Tegmental Area in the Mouse. Neuroscience 2008, 156, 700-711. [CrossRef] [PubMed]

68. Pomerleau, O.F.; Rosecrans, J. Neuroregulatory effects of nicotine. Psychoneuroendocrinology 1989, 14, 407-423. [CrossRef]

69. Barik, J.; Wonnacott, S. Molecular and Cellular Mechanisms of Action of Nicotine in the CNS. In Nicotine Psychopharmacology. Handbook of Experimental Pharmacology; Henningfield, J.E., London, E.D., Pogun, S., Eds.; Springer: Berlin/Heidelberg, Germany, 2009; Volume 192.

70. Qi, Z.; Tretter, F.; Voit, E.O. A heuristic model of alcohol dependence. PLoS ONE 2014, 9, e92221. [CrossRef] [PubMed]

71. Richardson, B.D.; Rossi, D.J. Recreational concentrations of alcohol enhance synaptic inhibition of cerebellar unipolar brush cells via pre- and postsynaptic mechanisms. J. Neurophysiol. 2017, 118, 267-279. [CrossRef] [PubMed]

72. Mark, F.; Zoltan, N. Variations on an inhibitory theme: Phasic and tonic activation of GABAA receptors. Nat. Rev. Neurosci. 2005, 6, 215-229.

73. Roberto, M.; Madamba, S.G.; Stouffer, D.G.; Parsons, L.H.; Siggins, G.R. Increased GABA release in the central amygdala of ethanol-dependent rats. J. Neurosci. 2004, 24, 10159-10166. [CrossRef] [PubMed]

74. Brousse, G.; Arnaud, B.; Vorspan, F.; Richard, D.; Dissard, A.; Dubois, M.; Pic, D.; Geneste, J.; Xavier, L.; Authier, N. Alteration of Glutamate/GABA Balance During Acute Alcohol Withdrawal in Emergency Department: A Prospective Analysis. Alcohol Alcohol. 2012, 47, 501-508. [CrossRef] [PubMed]

75. Banerjee, N. Neurotransmitters in alcoholism: A review of neurobiological and genetic studies. Indian J. Hum. Genet. 2014, 20, 20-31. [CrossRef] [PubMed]

76. Buck, K.J.; Harris, R.A. Benzodiazepine agonist and inverse agonist actions on GABAA receptor-operated chloride channels. II. Chronic effects of ethanol. J. Pharmacol. Exp. Ther. 1990, 253, 713-719.

77. Costin, B.N.; Miles, M.F. Molecular and neurologic responses to chronic alcohol use. Handb. Clin. Neurol. 2014, 125, 157-171. [PubMed]

78. Freed, J.W.; Michaelis, E.K. Glutamic acid and ethanol dependence. Pharm. Biochem. Behav. 1978, 8, 509-514. [CrossRef]

79. Acevedo-Rodriguez, A.; Zhang, L.; Zhou, F. Cocaine inhibition of nicotinic acetylcholine receptors influences dopamine release. Front. Synaptic Neurosci. 2014, 6, 19. [CrossRef] [PubMed]

80. Cheng, M.H.; Block, E.; Hu, F.; Cobanoglu, M.C.; Sorkin, A.; Bahar, I. Insights into the modulation of dopamine transporter function by amphetamine, orphenadrine, and cocaine binding. Front. Neurol. 2015, 6, 134. [CrossRef] [PubMed]

81. Goto, Y.; Grace, A.A. Dopaminergic modulation of limbic and cortical drive of nucleus accumbens in goal-directed behavior. Nat. Neurosci. 2005, 8, 805-812. [CrossRef] [PubMed]

82. Cook, M.N.; Ware, C.D.; Boone, E.M. Ethanol Modulates Cocaine-Induced Behavioral Change in Inbred Mice. Pharm. Biochem. Behav. 1998, 59, 567-575. [CrossRef] 
83. O'Malley, P.; Johnston, L.D. Epidemiology of Alcohol and Other Drug Use among American College Students. J. Stud. Alcohol 2002, S14, 23-39. [CrossRef]

84. Lewis, M.J.; June, H.L. Synergistic effects of ethanol and cocaine on brain simulation reward. J. Exp. Anal. Behav. 1994, 61, 223-229. [CrossRef] [PubMed]

85. Busse, G.D.; Lawrence, E.T.; Riley, A.L. The modulation of cocaine-induced conditioned place preferences by alcohol: Effects of cocaine dose. Prog. Neuro-Psychopharm. Biol. Psychiatry 2004, 28, 149-155. [CrossRef] [PubMed]

86. Knackstedt, L.A.; Ben-Shahar, O.; Ettenberg, A. Alcohol consumption is preferred to water in rats pre-treated with intravenous cocaine. Pharm. Biochem. Behav. 2006, 85, 81-286. [CrossRef] [PubMed]

87. Katner, S.N.; Oster, S.M.; Ding, Z.M.; Deehan, G.A., Jr.; Toalston, J.E.; Hauser, S.R.; McBride, W.A.; Rodd, Z.A. Alcohol-preferring $(\mathrm{P})$ rats are more sensitive than Wistar rats to the reinforcing effects of cocaine self-administered directly into the nucleus accumbens shell. Pharm. Biochem. Behav. 2011, 99, 688-695. [CrossRef] [PubMed]

88. Nurnberger, J.I., Jr.; Wiegand, R.; Bucholz, K. A family study of alcohol dependence: Co-aggregation of multiple disorders in relatives of alcohol-dependent probands. Arch. Gen. Psychiatry 2004, 61, 1246-1256. [CrossRef] [PubMed]

89. Hearn, W.L.; Rose, S.; Wagner, D.C. Cocaethylene is more potent than cocaine in mediating lethality. Pharmacol. Biochem. Behav. 1991, 39, 531-533. [CrossRef]

90. Bradberry, C.W.; Nobiletti, J.B.; Elsworth, J.D. Cocaine and Cocaethylene: Microdialysis Comparison of Brain Drug Levels and Effects on Dopamine and Serotonin. J. Neurochem. 1993, 60, 1429-1435. [CrossRef] [PubMed]

91. Raven, M.A.; Necessary, B.D.; Danluck, D.A.; Ettenberg, A. Comparison of the reinforcing and anxiogenic effects of intravenous cocaine and cocaethylene. Exp. Clin. Psychopharmacol. 2000, 8, 117-124. [CrossRef] [PubMed]

92. Hart, C.; Jatlow, P.; Sevarino, K.; McCance-Katz, E.F. Comparison of intravenous cocaethylene and cocaine in humans. Psychopharmacology 2000, 149, 153-162. [CrossRef] [PubMed]

93. Wilson, J.M.; Shannak, K.; Kish, S.J.; Levey, A.I.; Bergeron, C.; Deck, J.; Kalasinsky, K.; Ang, L.; Peretti, F.; Adams, V.I. Striatal dopamine, dopamine transporter, and vesicular monoamine transporter in chronic cocaine users. Ann. Neurol. 1996, 40, 428-439. [CrossRef]

94. Andrews, P. Cocaethylene Toxicity. J. Addict. Dis. 1997, 16, 75-84. [CrossRef] [PubMed]

95. Rodríguez-Álvarez, T.; Racamonde, I.; González-Mariño, I.; Borsotti, A.; Rodil, R.; Rodríguez, I.; Zuccato, E.; Quintana, J.B.; Castiglioni, S. Alcohol and cocaine co-consumption in two European cities assessed by wastewater analysis. Sci. Total Environ. 2015, 536, 91-98. [CrossRef] [PubMed]

96. Harris, D.S.; Everhart, E.T.; Mendelson, J.; Jones, R.T. The pharmacology of cocaethylene in humans following cocaine and ethanol administration. Drug Alcohol Depend. 2003, 72, 169-182. [CrossRef]

97. Herbst, E.D.; Harris, D.S.; Everhart, E.T.; Mendelson, J.J.; Jones, P.; Reese, T. Cocaethylene formation following ethanol and cocaine administration by different routes. Exp. Clin. Psychopharmacol. 2011, 19, 95-104. [CrossRef] [PubMed]

98. McCance-Katz, E.F.; Kosten, T.R.; Jatlow, P. Concurrent use of cocaine and alcohol is more potent and potentially more toxic than use of either alone-A multiple-dose study. Biol. Psychiatry 1998, 44, 250-259. [CrossRef]

99. Farré, M.; De La Torre, R.; González, M.L.; Teran, M.T.; Roset, P.N.; Menoyo, E.; Cami, J. Cocaine and alcohol interactions in humans: Neuroendocrine effects and cocaethylene metabolism. J. Pharm. Exp. Ther. 1997, 283, 164-176.

100. Gottschalk, P.C.; Kosten, T.R. Cerebral perfusion defects in combined cocaine and alcohol dependence. Drug Alcohol Depend. 2002, 68, 95-104. [CrossRef]

101. Robinson, J.E.; Heaton, R.K.; O’Malley, S.S. Neuropsychological functioning in cocaine abusers with and without alcohol dependence. J. Int. Neuropsychol. Soc. 1999, 5, 10-19. [CrossRef] [PubMed]

102. Kosten, T.R.; Cheeves, C.; Palumbo, J.; Kosten, T.R.; Cheeves, C.; Palumbo, J.; Seibyl, J.P.; Price, L.P.; Woods, S.W. Regional cerebral blood flow during acute and chronic abstinence from combined cocaine-alcohol abuse. Drug Alcohol Depend. 1998, 50, 187-195. [CrossRef]

103. Bolla, K.I.; Funderburk, F.R.; Cadet, J.L. Differential effects of cocaine and cocaine alcohol on neurocognitive performance. Neurology 2000, 54, 2285-2292. [CrossRef] [PubMed] 
104. Verdejo-García, A.; Pérez-García, M. Profile of executive deficits in cocaine and heroin polysubstance users: Common and differential effects on separate executive components. Psychopharmacology 2007, 190, 517-530. [CrossRef] [PubMed]

105. Dackis, C.A.; O'Brien, C.P. Cocaine dependence: A disease of the brain's reward centers. J. Subst. Abus. Treat. 2001, 21, 111-117. [CrossRef]

106. Koob, G.F.; Bloom, F.E. Cellular and molecular mechanisms of drug dependence. Science 1988, 242, 715-723. [CrossRef] [PubMed]

107. Wise, R.A.; Rompre, P.P. Brain dopamine and reward. Annu. Rev. Psychol. 1989, 40, 191-225. [CrossRef] [PubMed]

108. Koob, G.F.; Sanna, P.P.; Bloom, F.E. Neuroscience of addiction. Neuron 1998, 21, 467-476. [CrossRef]

109. Lindholm, S.; Rosin, A.; Dahlin, I.; Georgieva, J.; Franck, J. Ethanol administration potentiates cocaine-induced dopamine levels in the rat nucleus accumbens. Br. Res. 2001, 915, 176-184. [CrossRef]

110. Gautam, P.; Warner, T.D.; Kan, E.C.; Sowell, E.R. Executive function and cortical thickness in youths prenatally exposed to cocaine, alcohol and tobacco. Dev. Cogn. Neurosci. 2015, 16, 155-165. [CrossRef] [PubMed]

111. Makris, N.; Gasic, G.P.; Kennedy, D.N.; Hodge, S.M.; Kaiser, J.R.; JooLee, M.; WooKin, B.; Blood, A.J.; Evins, E.; Seidman, L. Cortical Thickness Abnormalities in Cocaine Addiction-A Reflection of Both Drug Use and a Pre-existing Disposition to Drug Abuse? Neuron 2008, 60, 174-188. [CrossRef] [PubMed]

112. Vearrier, D.; Greenberg, M.I.; Miller, S.N.; Okaneku, T.J.; Haggerty, D.A. Methamphetamine-History, Pathophysiology, Adverse Health Effects, Current Trends, and Hazards Associated with the Clandestine Manufacture of Methamphetamine. Disease-a-Month 2012, 58, 38-89. [CrossRef] [PubMed]

113. Salvatore, M.F.; Nejtek, V.A.; Khoshbouei, H. Prolonged increase in ser31 tyrosine hydroxylase phosphorylation in substantia nigra following cessation of chronic methamphetamine. Neurotoxicology 2018, 67, 121-128. [CrossRef] [PubMed]

114. Liang, M.; Liu, Y.; Zheng, N. Distribution of Methamphetamine and Its Metabolite Amphetamine in Acute and Subacute Ethanol-Methamphetamine Combination Abuse Model Rats. J. Anal. Toxicol. 2012, 36, 30-35. [CrossRef] [PubMed]

115. Blaker, A.L.; Yamamoto, B.K. Methamphetamine-Induced Brain Injury and Alcohol Drinking. J. Neuroimmune Pharm. 2018, 13, 53-63. [CrossRef] [PubMed]

116. Eisch, J.E.; Schmued, L.C.; Marshall, J.F. Characterizing cortical neuron injury with fluoro-jade labeling after a neurotoxic regimen of methamphetamine. Synapse 1998, 30, 329-333. [CrossRef]

117. Bujars, S.; Roche, D.J.; Lunny, K.; Moallem, N.R.; Couertney, K.E.; Allen, V.; Hartwell, E.; Leventhal, A.; Rohrbuagh, Y. The relationship between methamphetamine and alcohol use in a community sample of methamphetamine users. Drug Alcohol Depend. 2014, 142, 127-132. [CrossRef] [PubMed]

118. Vaghef, L.; Babri, S. The effect of escalating dose, multiple binge methamphetamine regimen and alcohol combination on spatial memory and oxidative stress markers in rat brain. J. Alcohol Drug Depend. 2014, 2, 159.

119. Furr, C.D.; Delva, J.; Anthony, J.C. The suspected association between methamphetamine ('ice') smoking and frequent episodes of alcohol intoxication: Data from the 1993 National Household Survey on Drug Abuse. Drug Alcohol Depend. 2000, 59, 89-93. [CrossRef]

120. Shimosato, K. Urinary excretion of p-hydroxylated methamphetamine metabolites in man. II. Effect of alcohol intake on methamphetamine metabolism. Pharm. Biochem. Behav. 1988, 29, 733-740. [CrossRef]

121. Kirkpatrick, M.G.; Gunderson, E.W.; Levin, F.R.; Foltin, R.W.; Hart, C.L. Acute and residual interactive effects of repeated administrations of oral methamphetamine and alcohol in humans. Psychopharmacology 2012, 219, 191-204. [CrossRef] [PubMed]

122. Mendelson, J.; Jones, R.T.; Upton, R.; Jacob, P. Methamphetamine and ethanol interactions in humans. Clin. Pharmacokinet. 1995, 57, 559-568. [CrossRef]

123. Wells, P.G.; Bhatia, S.; Drake, D.M. Fetal oxidative stress mechanisms of neurodevelopmental deficits and exacerbation by ethanol and methamphetamine. Birth Defects Res. Part C 2016, 108, 108-130. [CrossRef] [PubMed]

124. Andez-Lopez, C.H.; Farre, M.; Roset, P.N.; Menoyo, E.; Pizarro, N.; Ortuno, J.; Torrens, M.; Cami, J.; de la Torre, R. 3,4-Methylenedioxy-methamphetamine (Ecstasy) and Alcohol Interactions in Humans: Psychomotor Performance, Subjective Effects, and Pharmacokinetics. JPET 2002, 300, 236-244. [CrossRef]

125. Tolu, S.; Eddine, R.; Marti, F.C. Co-activation of VTA DA and GABA neurons mediates nicotine reinforcement. Mol. Psychiatry 2012, 2012, 1-12. [CrossRef] [PubMed] 
126. Benowitz, N.L.; Jones, R.T.; Jacob, P., III. Additive cardiovascular effects of nicotine and ethanol. Clin. Pharmacokinet. Ther. 1986, 40, 420-424. [CrossRef]

127. Perkins, K.A.; Sexton, J.E.; DiMarco, A.; Grobe, J.E.; Scierks, A.; Stiller, R.L. Subjective and cardiovascular responses to nicotine combined with alcohol in male and female smokers. Psychopharmacology 1995, 119, 205-212. [CrossRef] [PubMed]

128. Aliyu, M.H.; Wilson, R.E.; Zoorob, R.; Brown, K.; Alio, A.P.; Clayton, H.; Salihu, H.M. Prenatal alcohol consumption and fetal growth restriction: Potentiation effect by concomitant smoking. Nicotine Tobacco Res. 2009, 11, 36-43. [CrossRef] [PubMed]

129. Grant, B.F.; Hasin, D.S.; Chou, S.P.; Stinson, F.S.; Dawson, D.A. Nicotine dependence and psychiatric disorders in the United States: Results from the national epidemiologic survey on alcohol and relatedconditions. Arch. Gen. Psychiatry 2004, 61, 1107-1115. [CrossRef] [PubMed]

130. Burling, T.A.; Ziff, D.C. Tobacco smoking: A comparison between alcohol and drug abuse inpatients. Addict. Behav. 1988, 13, 185-190. [CrossRef]

131. DiFranza, J.R.; Guerrera, M.P. Alcoholism and smoking. J. Stud. Alcohol 1990, 51, 130-135. [CrossRef] [PubMed]

132. Batel, P.; Pessione, F.; Maitre, C.; Rueff, B. Relationship between alcohol and tobacco dependencies among alcoholics who smoke. Addiction 1995, 90, 977-980. [CrossRef] [PubMed]

133. Deehan, G.A., Jr.; Hauser, S.R.; Waeiss, R.A.; Toalston, J.E.; Truitt, W.A.; McBride, W.J.; Rodd, Z.A. Co-administration of ethanol and nicotine: The enduring alterations in the rewarding properties of nicotine and glutamate activity within the mesocorticolimbic system of female alcohol-preferring $(\mathrm{P})$ rats. Psychopharmacology 2015, 232, 4293-4302. [CrossRef] [PubMed]

134. Blomqvist, O.; Ericson, M.; Jörgen, E.A.; Soderpalm, B. Accumbal dopamine overflow after ethanol: Localization of the antagonizing effect of mecamylamine. Eur. J. Pharm. 1997, 334, 149-156. [CrossRef]

135. Blomqvist, O.; Nissbrandt, H.; Engel, J.A.; Soderpalm, B. The mesolimbic dopamine-activating properties of ethanol are antagonized by mecamylamine. Eur. J. Pharm. 1993, 249, 207-213. [CrossRef]

136. Truitt, W.A.; Hauser, S.R.; Deehan, G.A., Jr.; Toalston, J.E.; Wildem, J.A.; Brell, R.L.; McBride, W.J.; Rodd, Z.A. Ethanol and nicotine interaction within the posterior ventral tegmental area in male and female alcohol-preferring rats: Evidence of synergy and differential gene activation in the nucleus accumbens shell. Psychopharmacology 2015, 232, 639-649. [CrossRef] [PubMed]

137. Tolu, S.; Marti, F.; Morel, C.; Perrier, C.; Torquet, N.; Pons, S.; de Beaurepaire, R.; Faure, P. Nicotine enhances alcohol intake and dopaminergic responses through $\beta 2^{*}$ and $\beta 4^{*}$ nicotinic acetylcholine receptors. Sci. Rep. 2017, 7, 45116. [CrossRef] [PubMed]

138. Lüscher, C.; Malenka, R.C. Drug-evoked synaptic plasticity in addiction: From molecular changes to circuit remodeling. Neuron 2011, 69, 650-663. [CrossRef] [PubMed]

139. Larraga, A.; Belluzzi, J.D.; Leslie, F.M. Nicotine Increases Alcohol Intake in Adolescent Male Rats. Front. Behav. Neurosci. 2017, 11, 25. [CrossRef] [PubMed]

140. Larsson, A.; Engel, J.A. Neurochemical and behavioral studies on ethanol and nicotine interactions. Neurosci. Biobehav. Rev. 2004, 27, 713-720. [CrossRef] [PubMed]

141. Vowles, K.E.; McEntee, M.L.; Julnes, P.S.; Frohe, T.; Ney, J.P.; van der Goes, D.N. Rates of opioid misuse, abuse, and addiction in chronic pain: A systematic review and data synthesis. Pain 2015, 156, 569-576. [CrossRef] [PubMed]

142. Cicero, T.J.; Ellis, M.S.; Surratt, H.L. The changing face of heroin use in the United States: A retrospective analysis of the past 50 years. JAMA Psychiatry 2014, 71, 821-826. [CrossRef] [PubMed]

143. Stein, C. Opioid Receptors. Annu. Rev. Med. 2016, 67, 433-451. [CrossRef] [PubMed]

144. William, J. Basic Opioid Pharmacology. Rev. Pain 2016, 1, 2-5. [CrossRef] [PubMed]

145. Ikeda, K.; Kobayashi, T.; Kumanishi, T.; Yano, R.; Sora, I.; Niki, H. Molecular mechanisms of analgesia induced by opioids and ethanol: Is the GIRK channel one of the keys? Neurosci. Res. 2002, 44, 121-131. [CrossRef]

146. Janecka, A.; Fichna, J.T. Opioid Receptors and their Ligands. Curr. Top. Med. Chem. 2004, 4, 1-17. [CrossRef] [PubMed]

147. Herlitze, S.; Hockerm, G.H. Molecular determinants of inactivation and G protein modulation in the intracellular loop connecting domains I and II of the calcium channel $\alpha_{1 \mathrm{~A}}$ subunit. Proc. Natl. Acad. Sci. USA 1997, 94, 1512-1516. [CrossRef] [PubMed] 
148. Public Health Agency of Canada. National Report: Apparent Opioid-Related Deaths in Canada. 2017. Available online: https://www.canada.ca/en/public-health/services/publications/healthy-living/ apparent-opioid-related-deaths-report-2016-2017-december.html (accessed on 20 November 2018).

149. Food and Drug Administration [FDA]. Labels of Sublimaze (Fentanyl), Duragesic (Fentanyl), Fentora (Fentanyl), Actiq (Fentanyl), Alfenta (Alfentanil), Rapifen (Alfentanil), Sufenta (Sufentanil), Ultiva (Remifentanil), Avinza (Morphine Sulphate), Embeda (Morphine Sulfate and Naltrexone Hydrochloride), Duramorph (Morphine Sulfate Injection), Narcan Nasal Spray (Naloxone Hydrochloride), Evzio (Naloxone Hydrochloride), Naloxone West Ward Pharms Int. (Naloxone Hydrochloride), Entereg (Alvimopan), Vivitrol (Naltrexone for Extended-Release Injectable Suspension). 2018. Available online: https:/ / www.accessdata. fda.gov/scripts/cder/daf/index.cfm (accessed on 20 November 2018).

150. Weerts, E.M.; Wand, G.S.; Kuwabara, H.; Munro, C.A.; Dannals, R.F.; Hilton, J.; Frost, J.J.; McCaul, M.E. Positron Emission Tomography Imaging of $\mathrm{Mu}$ - and Delta-Opioid Receptor Binding in Alcohol-Dependent and Healthy Control Subjects. Alcohol. Clin. Exp. Res. 2011, 35, 2162-2173. [CrossRef] [PubMed]

151. Olive, M.F. Pharmacotherapies for Alcoholism: The Old and the New. CNS Neurol. Disord. Drug Targets 2010, 9, 2-4. [CrossRef] [PubMed]

152. Hermann, D.; Hirth, N.; Reimold, M.; Batra, A.; Smolka, M.N.; Hoffmann, S.; Kiefer, F.; Noori, H.R.; Sommer, W.H.; Reischl, G.; et al. Low $\mu$-Opioid Receptor Status in Alcohol Dependence Identified by Combined Positron Emission Tomography and Post-Mortem Brain Analysis. Neuropsychopharmacology 2017, 42, 606-614. [CrossRef] [PubMed]

153. Ceccarini, J.; Hompes, T.; Verhaeghen, A.; Casteels, C.; Peuskens, H.; Bormans, G.; Claes, S.; Van Laere, K. Changes in Cerebral CB1 Receptor Availability after Acute and Chronic Alcohol Abuse and Monitored Abstinence. J. Neurosci. 2014, 34, 2822-2831. [CrossRef] [PubMed]

154. Hillmer, A.T.; Mason, G.F.; Fucito, L.M.; O'malley, S.S.; Cosgrove, K.P. How Imaging Glutamate, $\gamma$-Aminobutyric Acid, and Dopamine Can Inform the Clinical Treatment of Alcohol Dependence and Withdrawal. Alcohol. Clin. Exp. Res. 2015, 39, 2268-2282. [CrossRef] [PubMed]

155. Laine, T.P.; Ahonen, A.; Rasanen, P.; Tlihonen, J. Dopamine Transporter Availability and Depressive Symptoms during Alcohol Withdrawal. Psychiatry Res. 1999, 90, 153-157. [CrossRef]

156. Polettini, A.; Poloni, V.; Groppi, A.; Stramesi, C.; Vignali, C.; Politi, L.; Montagna, M. The role of cocaine in heroin-related deaths. Hypothesis on the interaction between heroin and cocaine. Forensic Sci. Int. 2005, 4, 23-28. [CrossRef] [PubMed]

157. Thaulow, C.H.; Hoiseth, G.; Andersen, J.M.; Handal, M.; Morland, J. Pharmacokinetic interactions between ethanol and heroin: A study on post-mortem cases. Forensic Sci. Int. 2014, 242, 127-134. [CrossRef] [PubMed]

158. Kobayashi, T.; Ikeda, K.; Kojima, H.; Niki, H.; Yano, R.; Yoshioka, T.; Kumanishi, T. Ethanol opens G-protein-activated inwardly rectifying K+ channels. Nat. Neurosci. 1999, 2, 1091-1097. [CrossRef] [PubMed]

159. Blednov, Y.A.; Stoffel, M.; Chang, S.R.; Harris, R.A. Potassium Channels as Targets for Ethanol: Studies of G-Protein-Coupled Inwardly Rectifying Potassium Channel 2 (GIRK2) Null Mutant Mice. JPET 2001, 298, 521-530.

160. Blednov, Y.A.; Stoffel, M.; Alva, H.; Harris, R.A. A pervasive mechanism for analgesia: Activation of GIRK2 channels. Proc. Natl. Acad. Sci. USA 2003, 100, 277-282. [CrossRef] [PubMed]

161. Kunkel, M.T.; Peralta, E.G. Identification of domains conferring G protein regulation on inward rectifier potassium channels. Cell 1995, 83, 443-449. [CrossRef]

162. Nelson, L.R.; Taylor, A.N.; Lewis, J.W.; Branch, B.J.; Liebalind, C.J. Opioid but not nonopioid stress-induced analgesia is enhanced following prenatal exposure to ethanol. Psychopharmacology 1985, 85, 92-96. [CrossRef] [PubMed]

163. Kranzler, H.R.; Modesto-Lowe, V.; Nuwayser, E.S. Sustained-Release Naltrexone for Alcoholism Treatment: A Preliminary Study. Alcohol. Clin. Exp. Res. 1998, 22, 1074-1079. [CrossRef]

164. Zhang, H.; Luo, X.; Kranzler, H.R.; Lappalainen, J.; Yang, B.-Z.; Krupitsky, E.; Zvartau, E.; Gelernter, J. Association between two $\mu$-opioid receptor gene (OPRM1) haplotype blocks and drug or alcohol dependence. Hum. Mol. Genet. 2006, 15, 807-819. [CrossRef] [PubMed]

165. Chou, W.Y.; Yang, L.-C.; Lu, H.-F.; Ko, J.Y.; Wang, C.H.; Lin, S.H.; Lee, T.H.; Concejero, A.; Hsu, C.J. Association of $\mu$-opioid receptor gene polymorphism (A118G) with variations in morphine consumption for analgesia after total knee arthroplasty. Acta Anaesthesiol. Scand. 2006, 50, 787-792. [CrossRef] [PubMed] 
166. Schellekens, A.F.; Franke, B.; Ellenbroek, B.; Cools, A.; de Jong, C.A.; Buitelaar, J.K.; Verkes, R.J. Reduced Dopamine Receptor Sensitivity as an Intermediate Phenotype in Alcohol Dependence and the Role of the COMT Val158Met and DRD2 Taq1A Genotypes. Arch. Gen. Psychiatry 2012, 69, 339-348. [PubMed]

167. Hendershot, C.S.; Lindgren, K.P.; Liang, T.; Hutchison, K.E. COMT and ALDH2 polymorphisms moderate associations of implicit drinking motives with alcohol use. Addict. Biol. 2012, 17, 192-201. [CrossRef] [PubMed]

168. Drehera, J.C.; Kohn, P.; Kolachana, B.; Weinberger, D.R.; Berman, K.F. Variation in dopamine genes influences responsivity of the human reward system. Proc. Natl. Acad. Sci. USA 2009, 106, 617-622. [CrossRef] [PubMed]

169. Zubieta, J.K.; Mary, M.; Heitzeg, M.H. COMT val ${ }^{158}$ met Genotype Affects $\mu$-Opioid Neurotransmitter Responses to a Pain Stressor. Science 2003, 299, 1240-1243. [CrossRef] [PubMed]

170. Thompson, T.; Oram, C.; Correll, C.U.; Bueller, J.A.; Xu, K.; Xu, Y.; Koeppe, R.A.; Stohler, C.S.; Goldman, D. Analgesic Effects of Alcohol: A Systematic Review and Meta-Analysis of Controlled Experimental Studies in Healthy Participants. J. Pain 2017, 18, 5499-54510. [CrossRef] [PubMed]

171. Bass, M.B.; Friedman, H.J.; Lester, D. Antagonism of naloxone hyperalgesia by ethanol. Life Sci. 1978, 22, 1939-1946. [CrossRef]

172. Xiong, M.; Shiwalkar, N.; Reddy, K.; Shin, P.; Bekker, A. Neurobiology of Propofol Addiction and Supportive Evidence: What Is the New Development? Brain Sci. 2018, 8, 36. [CrossRef] [PubMed]

173. Li, C.-Y.; Mao, X.; Wei, L. Genes and (Common) Pathways Underlying Drug Addiction. PLoS Comput. Biol. 2008, 4, e2. [CrossRef] [PubMed]

174. Nestler, E.J. Is there a common molecular pathway for addiction? Nat. Neurosci. 2005, 8, 1445-1449. [CrossRef] [PubMed]

175. Gianoulakis, C. Endogenous Opioids and Addiction to Alcohol and other Drugs of Abuse. Curr. Top. Med. Chem. 2004, 4, 39-50. [CrossRef] [PubMed]

176. Oswald, L.M.; Wand, G.S. Receptor Knockout Mice. Opioids and alcoholism. Physiol. Behav. 2004, 81, 339-358. [CrossRef] [PubMed]

177. Corrigan, F.; Wu, Y.; Tuke, J. Alcohol-induced sedation and synergistic interactions between alcohol and morphine: A key mechanistic role for Toll-Like Receptors and MyD88-dependent signaling. Brain Behav. Immun. 2015, 45, 245-252. [CrossRef] [PubMed]

178. Corrigan, F.; Hutchinson, M. Are the effects of alcohol on the CNS influenced by Toll-like receptor signaling? Expert Rev. Clin. Immunol. 2012, 8, 201-203. [CrossRef] [PubMed]

179. Wachtel, S.R.; ElSohly, M.A.; Ross, S.A.; Ambre, J.; de Wit, H. Comparison of the subjective effects of Delta(9)-tetrahydrocannabinol and marijuana in humans. Psychopharmacology. 2002, 161, 331-339. [PubMed]

180. Felder, C.C.; Veluz, J.S.; Williams, H.L.; Briley, E.M.; Matsuda, L.A. Cannabinoid agonists stimulate both receptor- and non-receptor-mediated signal transduction pathways in cells transfected with and expressing cannabinoid receptor clones. Mol. Pharmacol. 1992, 42, 838-845. [PubMed]

181. Blankman., J.L.; Simon, G.M.; Cravatt, B.F. A Comprehensive Profile of Brain Enzymes that Hydrolyze the Endocannabinoid 2-Arachidonoylglycerol. Chem. Biol. 2007, 14, 1347-1356. [CrossRef] [PubMed]

182. Castillo, P.E.; Younts, T.J.; Chavez, A.E.; Hashimotodani, Y. Endocannabinoid signaling and synaptic function. Neuron 2012, 76, 70-81. [CrossRef] [PubMed]

183. Bloomfield, M.A.P.; Ashok, A.H.; Volkow, N.D.; Howes, O.D. The effects of $\Delta 9$-tetrahydrocannabinol on the dopamine system. Nature 2016, 539, 369-377. [CrossRef] [PubMed]

184. Parsons, L.H.; Hurd, Y.L. Endocannabinoid signaling in reward and addiction. Nat. Neurosci. 2015, 16, 579-594. [CrossRef] [PubMed]

185. Iversen, L. Cannabis and the brain. Brain 2003, 126, 1252-1270. [CrossRef] [PubMed]

186. Liguori, A.; Gatto, C.P.; Jarrett, D.B. Separate and combined effects of marijuana and alcohol on mood, equilibrium and simulated driving. Psychopharmacology 2002, 163, 399-405. [CrossRef] [PubMed]

187. Ramaekers, J.G.; Kuypers, K.P. Acute effects of 3, 4-methylenedioxymethamphetamine (MDMA) on behavioral measures of impulsivity: Alone and in combination with alcohol. Neuropsychopharmacology 2006, 31, 1048-1055. [CrossRef] [PubMed]

188. Martin, C.S.; Kaczynski, N.A.; Maisto, S.A.; Tarter, R.E. Polydrug use in adolescent drinkers with and without DSM-IV alcohol abuse and dependence. Alcohol. Clin. Exp. Res. 1996, 20, 1099-1108. [CrossRef] [PubMed] 
189. Agosti, V.; Edward, N.; Frances, L. Rates of psychiatric comorbidity among U.S. residents with lifetime cannabis dependence. Am. J. Drug Alcohol Abus. 2002, 28, 643-652. [CrossRef]

190. Terry-McElrath, Y.M.; O'Malley, O.M.; Johnston, L.D. Alcohol and Marijuana Use Patterns Associated With Unsafe Driving Among U.S. High School Seniors: High Use Frequency, Concurrent Use, and Simultaneous Use. J. Stud. Alcohol Drugs 2014, 31, 1048-1055. [CrossRef]

191. Giedd, J.N.; Snell, J.W.; Lange, N.; Rajapakse, J.C.; Casey, B.J.; Kozuch, P.L.; Vaituzis, A.C.; Vauss, Y.C.; Hamburger, S.D.; Kaysen, D.; et al. Quantitative magnetic resonance imaging of human brain development: Ages 4-18. Cereb Cortex 1996, 6, 551-560. [CrossRef] [PubMed]

192. Sowell, E.R.; Trauner, D.A.; Gamst, A.; Jerngan, T.L. Development of cortical and subcortical brain structures in childhood and adolescence: A structural MRI study. Dev Med. Child Neurol. 2002, 44, 4-16. [CrossRef] [PubMed]

193. Eichenbaum, H. The hippocampus and mechanisms of declarative memory. Behav. Br. Res. 1999, 103, 123-133. [CrossRef]

194. Aloi, J.; Blair, K.S.; Crum, K.I.; Meffert, H.; White, S.F.; Tyler, P.M.; Thornton, L.C.; Mobley, A.M.; Killanin, A.D.; Adams, K.O.; et al. Adolescents show differential dysfunctions related to Alcohol and Cannabis Use Disorder severity in emotion and executive attention neuro-circuitries. Neuroimage Clin. 2018, 19, 782-792. [CrossRef] [PubMed]

195. Oleson, E.B.; Cheer, J.F. A Brain on Cannabinoids: The Role of Dopamine Release in Reward Seeking. Cold Spring Harb. Perspect. Med. 2012, 2, a012229. [CrossRef] [PubMed]

196. Chen, J.P.; Paredes, W.; Li, J.; Lowinson, J.; Gardner, E.L. D9-Tetrahydrocannabinol produces naloxoneblockable enhancement of presynaptic basal dopamine efflux in nucleus accumbens of conscious, freely-moving rats as measured by intracerebral microdialysis. Psychopharmacology 1990, 102, 156-162. [CrossRef] [PubMed]

197. Cheer, J.F.; Wassum, K.M.; Sombers, L.A.; Heien, M.L.A.V.; Ariansen, J.L.; Aragona, B.J.; Phillips, P.E.M.; Wightman, R.M. Phasic dopamine release evoked by abused substances requires cannabinoid receptor activation. J. Neurosci. 2007, 27, 791-795. [CrossRef] [PubMed]

198. Hungund, B.L.; Basavarajappa, B.S.; Vadasz, C.; Kunos, G.; Rodriguez de Fonseca, F.; Colombo, G.; Serra, S.; Parsons, L.; Koob, G.F. Ethanol, endocannabinoids, and the cannabinoidergic signaling system. Alcohol. Clin. Exp. Res. 2002, 26, 565-574. [CrossRef] [PubMed]

199. Cohen, C.; Perrault, G.; Voltz, C.; Steinberg, R.; Soubrie, P. SR141716, a central cannabinoid (CB 1$)$ receptor antagonist, blocks the motivational and dopamine-releasing effects of nicotine in rats. Behav. Pharm. 2002, 13, 451-463. [CrossRef]

200. Guillot, C.R.; Blumenthal, H.; Zvolensky, J.; Schmidt, N.B. Anxiety sensitivity components in relation to alcohol and cannabis use, motives, and problems in treatment-seeking cigarette smokers. Addict. Behav. 2018, 82, 166-173. [CrossRef] [PubMed]

201. Szutorisz, H.; Hurd, Y.L. Epigenetic Effects of Cannabis Exposure. Biol. Psychiatry 2016, 79, 586-594. [CrossRef] [PubMed]

202. Parira, T.; Laverde, A.; Agudelo, M. Epigenetic Interactions between Alcohol and Cannabinergic Effects: Focus on Histone Modification and DNA Methylation. J. Alcohol Drug Depend. 2017, 5, 259. [CrossRef] [PubMed]

203. Dobs, Y.E.; Ali, M.M. The epigenetic modulation of alcohol/ethanol and cannabis exposure/co-exposure during different stages. Open Biol. 2019, 9, 180115. [CrossRef]

204. Hungund, B.L.; Szakall, I.; Adam, A.; Basavarajappa, B.S.; Vadasz, C. Cannabinoid CB1 receptor knockout mice exhibit markedly reduced voluntary alcohol consumption and lack alcohol-induced dopamine release in the nucleus accumbens. J. Neurochem. 2003, 84, 698-704. [CrossRef] [PubMed]

205. Subbanna, S.; Nagre, N.N.; Umapathy, N.S.; Pace, B.S.; Basavarajappa, B.S. Ethanol Exposure Induces Neonatal Neurodegeneration by Enhancing CB1R Exon1 Histone H4K8 Acetylation and Up-regulating CB1R Function causing Neurobehavioral Abnormalities in Adult Mice. Int. J. Neuropsychopharmacol. 2015, 18, 1-15. [CrossRef] [PubMed]

206. Nagre, N.N. CB1-receptor knockout neonatal mice are protected against ethanol?induced impairments of DNMT1, DNMT3A, and DNA methylation. J. Neurochem. 2015, 132, 429-442. [CrossRef] [PubMed]

207. Abel, T.; Zukin, R.S. Epigenetic targets of HDAC inhibition in neurodegenerative and psychiatric disorders. Curr. Opin. Pharmacol. 2008, 8, 57-64. [CrossRef] [PubMed] 
208. Renthal, W.; Nestler, E.J. Chromatin regulation in drug addiction and depression. Dialogues Clin. Neurosci. 2009, 11, 257-268. [PubMed]

209. Maitre, M. The $\gamma$-hydroxybutyrate signaling system in brain: Organization and functional implications. Prog. Neurobiol. 1997, 51, 337-361. [CrossRef]

210. Cash, C.D. Gamma hydroxybutyrate: An overview of the pros and cons for it being an neurotransmitter and/or a useful therapeutic agent. Neurosci. Biobehav. Rev. 1994, 18, 291-304. [CrossRef]

211. Wong, C.G.T.; Chan, K.F.Y.; Gibson, K.M.; Snead, O.C. $\gamma$-Hydroxybutyric. Toxicol. Rev. 2004, 23 , 3-20. [CrossRef] [PubMed]

212. Cooper, F.J.; Logan, B.K. GHB and driving impairment. J. Forensic Sci. 2001, 46, 919-923. [CrossRef]

213. Mattila, M.J.; Palva, E.; Seppälä, T.; Ostrovskaya, R.U. Actions and interactions with alcohol of drugs on psychomotor skills: Comparison of diazepam and gamma-hydroxybutyric acid. Arch. Int. Pharmacodyn. 1978, 234, 236-246. [PubMed]

214. Nicholson, K.L.; Balster, R.L. GHB: A new and novel drug of abuse. Drug Alcohol Depend. 2001, 63, 1-22. [CrossRef]

215. McCabe, E.R.; Layne, E.C.; Sayler, D.F. Synergy of ethanol and a natural soporific—Gamma hydroxybutyrate. Science 1971, 171, 404-406. [CrossRef] [PubMed]

216. O'Connell, T.; Kaye, L.; Plosay, J.J. Gamma-Hydroxybutyrate (GHB): A Newer Drug of Abuse. Am. Fam. Physician 2000, 62, 2478-2482. [PubMed]

217. Ropero-Miller, J.D.; Goldberger, B.A. Recreational drugs. Current trends in the 90s. Clin. Lab Med. 1998, 18, 727-746. [CrossRef]

218. Li, J.; Stokes, S.A.; Woeckener, A. A tale of novel intoxication: A review of the effects of gamma-hydroxybutyric acid with recommendations for management. Ann. Emerg. Med. 1998, 31, 729-736. [CrossRef]

219. Galloway, G.P.; Frederick, S.L.; Staggers, F.E.; Gonzales, M.; Stalcup, S.A.; Smith, D.E. Gamma-hydroxybutyrate: An emerging drug of abuse that causes physical dependence. Addiction 1997, 92, 89-96. [CrossRef] [PubMed]

(c) 2019 by the author. Licensee MDPI, Basel, Switzerland. This article is an open access article distributed under the terms and conditions of the Creative Commons Attribution (CC BY) license (http://creativecommons.org/licenses/by/4.0/). 